\title{
The seasonal vertical distribution of the Saharan Air Layer and its modulation by the wind
}

\author{
C. Tsamalis ${ }^{1, *}$, A. Chédin ${ }^{1}$, J. Pelon ${ }^{2}$, and V. Capelle ${ }^{1}$ \\ ${ }^{1}$ Laboratoire de Météorologie Dynamique, UMR8539, CNRS - IPSL, Ecole Polytechnique, Palaiseau, France \\ ${ }^{2}$ UPMC Univ. Paris 06, UMR8190, CNRS/INSU - Université Versailles St-Quentin, LATMOS-IPSL, Paris, France \\ *now at: Met Office, Exeter, UK
}

Correspondence to: C. Tsamalis (christoforos.tsamalis@metoffice.gov.uk)

Received: 1 February 2013 - Published in Atmos. Chem. Phys. Discuss.: 19 February 2013

Revised: 25 September 2013 - Accepted: 14 October 2013 - Published: 19 November 2013

\begin{abstract}
The Saharan Air Layer (SAL) influences largescale environment from western Africa to eastern tropical Americas, by carrying large amounts of dust aerosols. However, the vertical distribution of the SAL is not well established due to a lack of systematic measurements away from the continents. This can be overcome by using the observations of the spaceborne lidar CALIOP onboard the satellite CALIPSO. By taking advantage of CALIOP's capability to distinguish dust aerosols from other types of aerosols through depolarization, the seasonal vertical distribution of the SAL is analyzed at $1^{\circ}$ horizontal resolution over a period of $5 \mathrm{yr}$ (June 2006-May 2011). This study shows that SAL can be identified all year round displaying a clear seasonal cycle. It occurs higher in altitude and more northern in latitude during summer than during winter, but with similar latitudinal extent near Africa for the four seasons. The south border of the SAL is determined by the Intertropical Convergence Zone (ITCZ), which either prohibits dust layers from penetrating it or reduces significantly the number of dust layers seen within or south of it, as over the eastern tropical Atlantic. Spatially, near Africa, it is found between $5^{\circ} \mathrm{S}$ and $15^{\circ} \mathrm{N}$ in winter and $5-30^{\circ} \mathrm{N}$ in summer. Towards the Americas $\left(50^{\circ} \mathrm{W}\right), \mathrm{SAL}$ is observed between $5^{\circ} \mathrm{S}$ and $10^{\circ} \mathrm{N}$ in winter and $10-25^{\circ} \mathrm{N}$ in summer. During spring and fall, SAL is found between the position of winter and summer not only spatially but also vertically. In winter, SAL occurs in the altitude range $0-3 \mathrm{~km}$ off western Africa, decreasing to $0-2 \mathrm{~km}$ close to South America. During summer, SAL is found to be thicker and higher near Africa at $1-5 \mathrm{~km}$, reducing to $0-2 \mathrm{~km}$ in the Gulf of Mexico, farther west than during the other seasons. SAL is confined to one layer, of which the mean alti-
\end{abstract}

tude decreases with westward transport by $13 \mathrm{~m} \mathrm{deg}^{-1}$ during winter and $28 \mathrm{~m} \mathrm{deg}^{-1}$, after $30^{\circ} \mathrm{W}$, during summer. Its mean geometrical thickness decreases by $25 \mathrm{~m} \mathrm{deg}^{-1}$ in winter and $9 \mathrm{~m} \mathrm{deg}^{-1}$ in summer. Spring and fall present similar characteristics for both mean altitude and geometrical thickness. Wind plays a major role not only for the transport of dust within the SAL but also by sculpting it. During winter, the trade winds transport SAL towards South America, while in spring and summer they bring dust-free maritime air masses mainly from the North Atlantic up to about $50^{\circ} \mathrm{W}$ below the SAL. The North Atlantic westerlies, with their southern border occurring between 15 and $30^{\circ} \mathrm{N}$ (depending on the season, the longitude and the altitude), prevent the SAL from developing further northward. In addition, their southward shift with altitude gives SAL its characteristic oval shape in the northern part. The effective dry deposition velocity of dust particles is estimated to be $0.07 \mathrm{~cm} \mathrm{~s}^{-1}$ in winter, $0.14 \mathrm{~cm} \mathrm{~s}^{-1}$ in spring, $0.2 \mathrm{~cm} \mathrm{~s}^{-1}$ in summer and $0.11 \mathrm{~cm} \mathrm{~s}^{-1}$ in fall. Finally, the African Easterly Jet (AEJ) is observed to collocate with the maximum dust load of the SAL, and this might promote the differential advection for SAL parts, especially during summer.

\section{Introduction}

It is well known that large quantities of Saharan dust are transported across the tropical Atlantic throughout the year as a result of large-scale Saharan dust outbreaks, with the maximum number of events occurring during summer. These dust outbreaks are mostly confined to a deep mixed layer, 
commonly referred to as the Saharan Air Layer (SAL), that can reach North America during summer and South America during winter. SAL is characterized not only by its load in dust aerosols but also by dry and warm air (Dunion and Marron, 2008). The SAL long-range transport is enhanced by the persistent temperature inversions that exist at its base and top, in part because of the interaction of dust aerosols with radiation, thus keeping the SAL relatively warm and stable in relation to its environment as it crosses the Atlantic (Karyampudi et al., 1999). However, both the dust and low humidity are essential for maintaining the temperature structure from thermal relaxation in the SAL (Wong et al., 2009).

SAL, due to its load of dust aerosols, influences in many ways the tropical environment from western Africa to the Americas. The interaction of dust with radiation through scattering and absorption in the visible and thermal infrared spectra heats the lower atmosphere within the dust layer over the tropical Atlantic Ocean (Alpert et al., 1998; Wang, 2009; Davidi et al., 2012), thus affecting locally the radiative budget and modifying the atmospheric stability. Simultaneously, the impact of dust on radiation affects the ocean temperature over the tropical Atlantic on interannual to decadal timescales (Evan et al., 2009, 2011). A robust negative correlation between atmospheric dust loading and Atlantic sea surface temperature is found, consistent with the notion that increased (decreased) Saharan dust is associated with cooling (warming) of the Atlantic during the early hurricane season (July to September) (Lau and Kim, 2007). Wu (2007) found also an anticorrelation between SAL activity and hurricane intensity and Evan et al. (2006) reported that SAL can suppress tropical cyclogenesis, while Jenkins et al. (2008) mentioned the possible role of Saharan dust in the invigoration of convective bands associated with tropical cyclogenesis. The tropical cyclone genesis and development may be affected by the enhancement of the vertical shear, which takes place to the south of the SAL due to dust-radiation effects (Chen et al., 2010). During the last years the connection of SAL with the activity of tropical cyclones has become an active research area (Dunion and Velden, 2004; Sun et al., 2008; Zipser et al., 2009) because of their strong socio-economic impacts. However, a recent study noticed that the SAL's thermodynamic and kinematic properties are not a determining factor for the intensity change of tropical cyclones once they become named storms (Braun, 2010), although the dust impacts were not taken into account. On the other hand, SAL suppresses convection over the eastern and central tropical North Atlantic (Wong and Dessler, 2005), where the dust load is important.

Further, SAL can shift rainfall northward by 1 to $4^{\circ}$ along the Intertropical Convergence Zone (ITCZ) (Wilcox et al., 2010). In addition, Saharan dust may serve as cloud condensation nuclei or ice nuclei, affecting cloud microphysics and decreasing precipitation (DeMott et al., 2003; Mahowald and Kiehl, 2003; Twohy et al., 2009). During dust events, the concentration of trace gases - like ozone, nitrogen oxides and or- ganic radicals - is reduced due to heterogeneous reactions on dust aerosols (de Reus et al., 2005; Jenkins et al., 2012), thus changing the oxidizing capacity of the atmosphere. Besides, SAL dust aerosols fertilize large areas of the Atlantic Ocean and Amazon Basin by transport and deposition of micronutrients, like iron and phosphorus, which in turn may impact many biogeochemical cycles (Jickells et al., 2005; Kaufman et al., 2005; Bristow et al., 2010). It should be noted that the deposition rates strongly depend on the vertical dust distribution, which varies with seasons (Schepanski et al., 2009).

The SAL has been studied at dedicated sites with observations at both sides of the tropical Atlantic (e.g., Chiapello et al., 1995; Prospero and Lamb, 2003), during specific campaigns (e.g., Reid et al., 2002; Ansmann et al., 2009) or using space observations (e.g., Zhu et al., 2007; Doherty et al., 2008). Some campaigns have used lidar observations in order to describe the vertical distribution of SAL, e.g., LITE, SHADE, AMMA, SAMUM, AMAZE-08 and SALTRACE. However, local measurements do not offer a global and complete view of dust outbreaks due to the lack of systematic measurements away from the continents. The same holds for campaigns, by definition limited in time, although they provide a plethora of observations at the regional scale. Satellite observations can describe the whole phenomenon on a daily basis, offering an almost global coverage (depending on the swath width). Nevertheless, the retrieval of thermodynamic variables from space, like temperature, is affected by the presence of dust (Zhang and Zhang, 2008; Maddy et al., 2012). On the other hand, aerosol satellite measurements in the solar spectrum mostly provide column-integrated properties like the optical depth, without any information about the vertical distribution. Indeed, the vertical global structure of the SAL has been paid little attention, in part due to the lack of available measurements before the CALIPSO mission. However, the vertical distribution of dust aerosols is a key parameter for the radiative forcing, both in solar and terrestrial spectra (Liao and Seinfeld, 1998; Meloni et al., 2005; Shell and Somerville, 2007). In addition, the satellite observations of dust are sensitive to the vertical distribution, especially in the ultraviolet and infrared spectra, which makes the retrieval of dust characteristics from space more challenging (Quijano et al., 2000; Ginoux and Torres, 2003; Pierangelo et al., 2004; Torres et al., 2007). At the same time, this sensitivity permits for new generation infrared sounders to bring reliable information on the dust layer mean altitude (Peyridieu et al., 2010, 2013), but their new established results still need further validation. An accurate determination of the aerosol vertical distribution at the global scale can be achieved with the two-wavelength polarization-sensitive lidar CALIOP, launched onboard CALIPSO in April 2006 (Winker et al., 2007).

Recent studies using CALIPSO data have examined the vertical structure of SAL, but these were either case studies (e.g., Liu et al., 2008b; Ben-Ami et al., 2010), and thus restricted in time, or climatological studies (Generoso et al., 
2008; Liu et al., 2008a; Ben-Ami et al., 2009; Braun, 2010; Yu et al., 2010; Adams et al., 2012; Ridley et al., 2012; Yang et al., 2012), restricted to the description of dust vertical distribution by presenting means at the regional scale or were less focused. In these studies mainly previous versions of CALIPSO data have been used, which showed significant errors regarding the discrimination between clouds and aerosols. Here, the seasonal vertical distribution of the SAL at $1^{\circ}$ spatial resolution is presented based on $5 \mathrm{yr}$ of CALIPSO observations, bringing a more detailed description of its spatial structure at a relatively fine scale. Furthermore, the CALIPSO aerosol types desert dust and polluted dust are combined to avoid the potential misclassification of desert dust aerosols as polluted dust in the algorithm. This combination allows also for aging of dust aerosols with transport to be better accounted for. In this study, data from ECMWF (European Centre for Medium-Range Weather Forecasts) reanalysis are also used in order to examine the influence of wind on the SAL shape. The data and method are described in Sect. 2. Section 3 presents the vertical distribution of the SAL. The connection between SAL and wind is presented in Sect. 4, and finally the summary and conclusions are given in Sect. 5.

\section{Data}

\subsection{CALIPSO data and methodology}

CALIOP has provided data since June 2006, and it is the primary instrument onboard CALIPSO, which is part of the "ATrain" constellation of satellites. This space lidar is based on a Nd: YAG laser measuring the backscatter signal at 532 and $1064 \mathrm{~nm}$ and the degree of linear polarization at $532 \mathrm{~nm}$. CALIOP observes aerosols and clouds with high vertical resolution of 30-60 m (up to $20 \mathrm{~km}$ ) during its 16-day repeat cycle, while its beam diameter is about $70 \mathrm{~m}$ at the Earth's surface (Winker et al., 2007). Winker et al. (2009) provide an overview of CALIPSO data products and of the algorithms used to produce them. In this study, we use CALIPSO level 2 data, the $5 \mathrm{~km}$ aerosol layer product (version 3.01) above the Atlantic for the $5 \mathrm{yr}$ period June 2006-May 2011.

In CALIOP data, the layer (aerosol or cloud) boundaries are identified with a multiscale retrieval approach in order to achieve an optimum balance between the signal-to-noise ratio and spatial resolution (Vaughan et al., 2009). The aerosol layer product is reported at the resolution of $5 \mathrm{~km}$, which is not always equal to the detection resolution $(0.333,1,5,20$ or $80 \mathrm{~km}$ ). The signal of layers detected at finer resolution is removed before moving on to further averaging. However, layers detected with finer resolution may appear to overwrite or overlap in the vertical dimension with layers found at coarser resolution. In order to avoid counting several times the same layer, this overwriting has been corrected. When two or more layers appear to overlap in a column of $5 \mathrm{~km}$, the top is de- fined as the maximum top altitude of the overlapping layers and the bottom accordingly as the minimum base altitude of the layers. A similar correction was applied by Thorsen et al. (2011) in the case of cirrus clouds. Figure 1 presents an example of CALIOP signal cross section (top) above the Atlantic. The triangles show the boundaries of dust layers (see below for their definition) as detected by CALIPSO algorithms, while the white lines indicate the overlap.

CALIPSO discriminates between clouds and aerosols based on statistical differences in their optical and physical properties by using five-dimensional probability distribution functions in version 3 (Liu et al., 2009, 2010). The confidence level of discrimination is provided by the cloudaerosol discrimination (CAD) score, which ranges from -100 to 100 , with negative values indicating aerosols and high absolute values meaning high confidence. Here, only aerosol layers with high confidence of discrimination are used with feature type quality assessment (QA) equal to 3, corresponding to CAD score $\leq-70$. It should be mentioned that some misclassification of dust aerosols as clouds (mostly cirrus) may still occur in the case of moderately dense dust plumes transported to high latitudes or to high altitudes even at low latitudes. This happens very rarely over the ocean, and high resolution can be helpful to improve misclassifications.

Once the layer has been identified as aerosol, then an algorithm classifies it as one of the six defined types: desert dust, smoke, clean continental, polluted continental, clean marine and polluted dust (Omar et al., 2009). Using depolarization at $532 \mathrm{~nm}$, CALIOP is able to discriminate between dust and other types of aerosols (smoke, continental, marine), which generally do not depolarize light as they are mainly spherical (e.g., Iwasaka et al., 2003; Ansmann et al., 2009; Winker et al., 2010). Indeed, the better identification of dust aerosols in comparison to other types from CALIOP has been confirmed with AERONET measurements, with agreement percentages of 91 and $53 \%$ for dust and polluted dust aerosol types, respectively (Mielonen et al., 2009). Polluted dust corresponds to low depolarization values $(<20 \%)$, and this type of aerosol is detected about $20 \%$ of the time (Omar et al., 2009). There are, however, some misclassification issues, and polluted dust is expected to be identified too often (D. Winker, personal communication, 2012).

In order to take into account the possible change of dust aerosol properties with transport, the two CALIPSO types desert dust and polluted dust are thus combined in our analysis, with their sum stated as dust for the rest of the study. Indeed, after their emission from northern Africa, dust aerosols can be mixed with other types of aerosols like biomass burning or anthropogenic pollution and then transported further away (Ansmann et al., 2009; Rodriguez et al., 2011). On the other hand, above the ocean they can be mixed with maritime aerosols (Knippertz et al., 2011; Yang et al., 2012). Also, dust aerosols can uptake trace gases on their surface (Andreae and Crutzen, 1997; Formenti et al., 2011), thus changing their composition and finally their optical characteristics. Away 
from the Sahara, the inclusion of polluted dust layers may alter the results because of the non-desert origin of some of these layers. Consequently, away from the Sahara and close to biomass burning or pollution sources, like over Africa and South America, results are treated with caution and, as far as possible, this is discussed in this paper and a statement is issued. The good quality of dust detection from the CALIPSO algorithms can be observed in Fig. 1, where an example of SAL is presented. CALIPSO captures adequately the top and the base of the dust layers (indicated by the triangles), while it avoids the misclassification of dust as cloud and vice versa (clouds are shown as dark-brown features).

CALIOP as a lidar has a very small swath width, while the distance between two successive CALIPSO tracks is more than $2000 \mathrm{~km}$ in the low and mid-latitudes. As a result, a considerable averaging in space and in time is required for producing statistically meaningful results (Winker et al., 2010). Here, seasonal means with $1^{\circ}$ resolution are calculated using the first $5 \mathrm{yr}$ of CALIOP's available observations, including both nighttime and daytime data. The nighttime data have a better signal-to-noise ratio (Wu et al., 2011), and this is reflected in the percentage of daytime layers to the total number of layers, which is about $30 \%$. In order to ensure a minimum level of statistical significance, the number of at least 240 layers is imposed for every $1^{\circ}$ bin.

In order to avoid the dependence of the results on the lidar ratio, which is ill constrained by CALIOP as an elastic lidar, the occurrence frequency is used instead. The lidar ratio for dust aerosols can vary significantly between 20 and $100 \mathrm{sr}$ (Mattis et al., 2002; Balis et al., 2004), while statistical studies indicate values mostly between 30 and $70 \mathrm{sr}$ (Cattrall et al., 2005; Muller et al., 2007). Different dust source regions have distinct lidar ratios (Muller et al., 2007), while even within the Sahara the variability of the lidar ratio is significant (Schuster et al., 2012). In the CALIPSO algorithm the lidar ratio at $532 \mathrm{~nm}$ is set to $40 \mathrm{sr}$ for desert dust and to $55 \mathrm{sr}$ for polluted dust aerosols (it was $65 \mathrm{sr}$ in version 2), within the range of possible lidar ratios for dust aerosols. However, recent studies comparing CALIOP aerosol optical depth with other instruments reveal that CALIOP is generally biased low (Breon et al., 2011; Kittaka et al., 2011; Redemann et al., 2012), especially in the case of dust aerosols (Wandinger et al., 2010; Schuster et al., 2012). The dust occurrence frequency (DOF) used here is given by the equation

$\operatorname{DOF}(x, y, z)=\frac{\text { number of layers }(x, y, z)}{\text { total number of layers in the } \operatorname{bin}(x, y)}$.

It is reported with vertical resolution of $100 \mathrm{~m}$ and horizontal resolution of $1^{\circ}$ so as to take advantage of the highresolution measurements and better account for local cloud obscuration (nonlinearity in the calculation of the DOF). It can be further smoothed, but this was not done here, in order to keep track of the variability. In Eq. (1), according to previous paragraphs, "number of layers" (at a specific altitude $z$

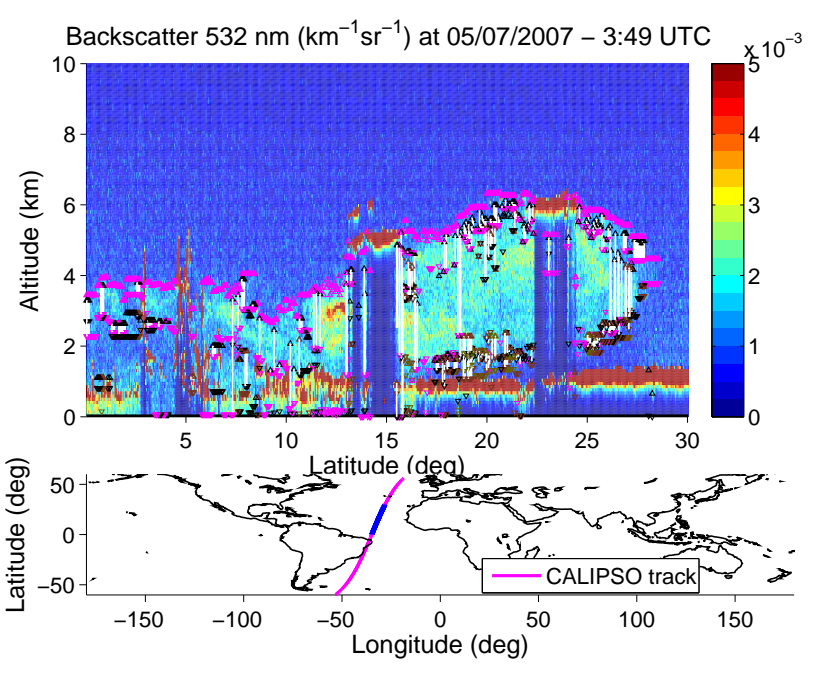

Fig. 1. An example of SAL as observed from CALIOP on 5 July 2007 at 03:49 UTC. Top: the latitude-altitude cross section of the attenuated backscatter coefficient at $532 \mu \mathrm{m}\left(\mathrm{km}^{-1} \mathrm{sr}^{-1}\right)$. The brown features at about $1 \mathrm{~km}$ and the elevated ones at about 5, 15 and $22^{\circ} \mathrm{N}$ are clouds. The white lines mark the overlap (see text for details) and the triangles (magenta, black or brown) show the top and the base of dust layers as detected by CALIPSO. Bottom: the CALIPSO track, with the part of the cross section presented above highlighted in blue.

or in total inside the $1^{\circ}$ bin) stands for dust layers (desert and polluted dust) detected by CALIPSO with the highest quality discrimination from clouds (Feature type $\mathrm{QA}=3$ ) and after accounting for the vertical overlap in case that occurs. Also, it should be noted that the lidar signal does not penetrate optically thick clouds, and thus the systematic presence of clouds in some regions and/or at specific altitudes impacts on DOF (one can note that all remote sensing instruments measuring aerosols are affected by clouds and generally the given results are biased towards cloud-free conditions). The presence of semi-transparent clouds is much less an issue as the lidar can penetrate and the backscattered signal from below can be analyzed to retrieve aerosol layers (Winker et al., 2013). Nevertheless, the clouds' impact is expected to be minimal here, as only the number of dust layers with the aforementioned quality criteria is used in the estimation of DOF, instead of the total number of CALIPSO observations or cloud-free observations only.

Figure 2 shows the number of dust layers $(N)$ detected by CALIPSO at every bin for the four seasons. The spatial distribution of SAL (where $N$ is greater than about 500) and its northward shift between winter and summer can be observed clearly. A similar seasonal spatial distribution of dust above the Atlantic has been provided by MODIS dust optical depth (Ben-Ami et al., 2012, ; see their Fig. 1). 


\subsection{Additional data sets}

The MODIS/AQUA aerosol optical depth (AOD) at $550 \mathrm{~nm}$ (level 3, collection 5.1), which has a spatio-temporal resolution of $1^{\circ}$ and 1 month, is used for the same period. The aerosol characteristics from MODIS are derived over the land and oceans separately, using independent algorithms, while a third algorithm is used above bright surfaces, such as deserts (Remer et al., 2005). Comparison of MODIS AOD retrievals with collocated AERONET measurements confirms that 1 standard deviation of MODIS AOD falls within the initial predicted uncertainty of $\Delta \tau= \pm 0.03 \pm 0.05 \tau$ over ocean and $\Delta \tau= \pm 0.05 \pm 0.15 \tau$ over land, more than $60 \%$ of the time over ocean and more than $72 \%$ of the time over land (Remer et al., 2005, 2008). It should be noted that MODIS observations have been used extensively to study dust aerosols above the Atlantic Ocean (e.g., Kaufman et al., 2005; Wong and Dessler, 2005; Kalashnikova and Kahn, 2008; Peyridieu et al., 2010; Ben-Ami et al., 2012; Peyridieu et al., 2013) due to their almost global coverage of the Earth on a daily basis, their availability from both TERRA and AQUA satellites and their good quality. MODIS AOD is used here as an additional constraint to DOF from CALIPSO regarding the spatial distribution of the SAL. AOD, being a parameter independent of DOF, offers an external validation of DOF, meaning that maxima (minima) of DOF should collocate with AOD maxima (minima). In Fig. 2 the MODIS 0.25 AOD isolines are superimposed to the number of dust layers detected by CALIPSO. As both parameters are column integrated, they can be directly compared. It can be seen that the areas with significant number of dust layers are mostly included in the 0.25 AOD isolines. This indicates that MODIS and CALIPSO are generally in agreement regarding the spatial occurrence of the SAL. However, some differences exist in winter and spring close to Africa south of the Equator, in summer above the mid-Atlantic north of $20^{\circ} \mathrm{N}$ and in fall west of $30^{\circ} \mathrm{W}$. Nevertheless, these differences are minimized by plotting the MODIS 0.2 AOD isolines, especially in winter and spring, while in fall the differences persist west of $40^{\circ} \mathrm{W}$ (not shown). The discrepancies between CALIPSO's number of dust layers and MODIS's AOD in summer and fall will be further discussed in the next section. In any case it should be kept in mind when comparing the two quantities that a big number of dust layers does not necessarily mean that the layers are optically thick, especially far away from the Sahara or near the boundaries of SAL.

Wind strongly influences dust emission and transport (e.g., Maher et al., 2010). In order to examine the impact that the wind may have on SAL during its transport, wind data from ERA-Interim are used for the $5 \mathrm{yr}$ of the study. ERAInterim is the latest global atmospheric reanalysis produced by the ECMWF (Dee et al., 2011). The data are provided at a spectral T255 horizontal resolution, which corresponds to approximately $79 \mathrm{~km}$ spacing on a reduced Gaussian grid and at 37 pressure levels (from 1000 to $1 \mathrm{hPa}$ ). Here, the monthly

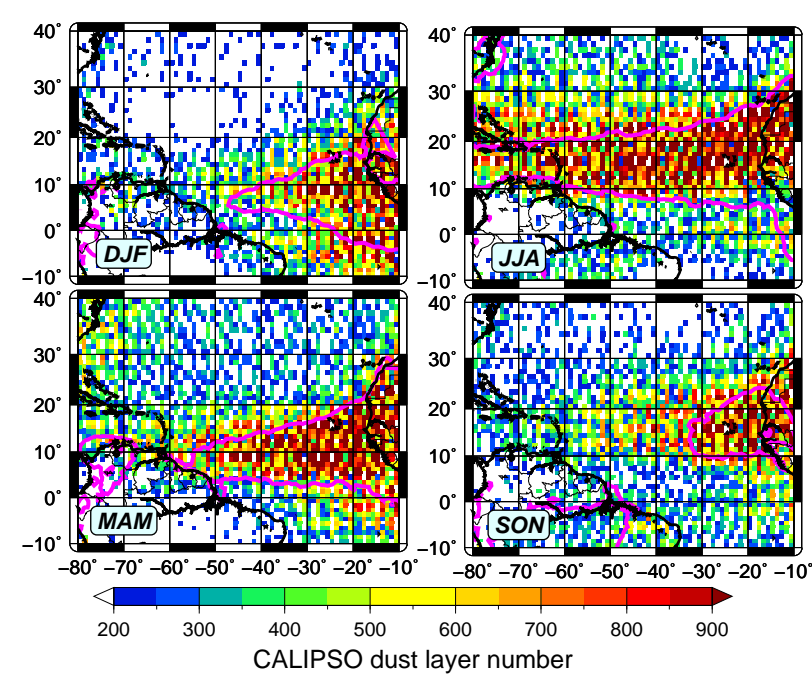

Fig. 2. Number of dust layers (desert dust and polluted dust) detected by CALIPSO above the Atlantic during the $5 \mathrm{yr}$ period from June 2006 to May 2011 for the four seasons: winter (DJF - top left), spring (MAM - bottom left), summer (JJA - top right) and fall (SON - bottom right). The magenta lines are the 0.25 AOD isolines from MODIS for each season.

means of daily means are used, as they are representative for the entire month. The monthly means are then averaged to seasonal means in order to be consistent with our CALIPSO data set.

\section{SAL seasonal vertical distribution}

Figures 3 and 4 depict the seasonal vertical distribution of the SAL above the Atlantic Ocean as depicted from CALIPSO measurements of dust aerosols. For each season, five latitude ( $x$ axis)-altitude ( $y$ axis) cross sections of DOF are shown with the latitude ranging from $10^{\circ} \mathrm{S}$ to $40^{\circ} \mathrm{N}$, from the west coast of northern Africa $\left(10^{\circ} \mathrm{W}\right.$, bottom) to the east coast of South America and the east side of the Caribbean Sea $\left(50^{\circ} \mathrm{W}\right.$, top) with a step of $10^{\circ}$. Although our database is available at a resolution of $1^{\circ}$, each cross section presents the meridional average of $\pm 1^{\circ}$ around the central longitude in order to increase the number of available data and to reduce the noise. The continuous bold color line at the top of each cross section shows the MODIS AOD at $550 \mathrm{~nm}$. Note that the MODIS AOD at $10^{\circ} \mathrm{W}$ is not available from the standard algorithm above the Sahara. White areas denote either very low DOF $(<0.05)$ or a statistically insignificant number of dust layers $\left(<480\right.$ for the $\pm 1^{\circ}$ average). It can be seen in Figs. 3 and 4 that dust aerosols above the tropical Atlantic are not found in general above the altitude level of $6.5 \mathrm{~km}$ $(\mathrm{DOF}<0.05$ above it) all year round. An obvious seasonal cycle can also be noticed with the SAL being in contact with the surface and confined within a thin layer during winter, 

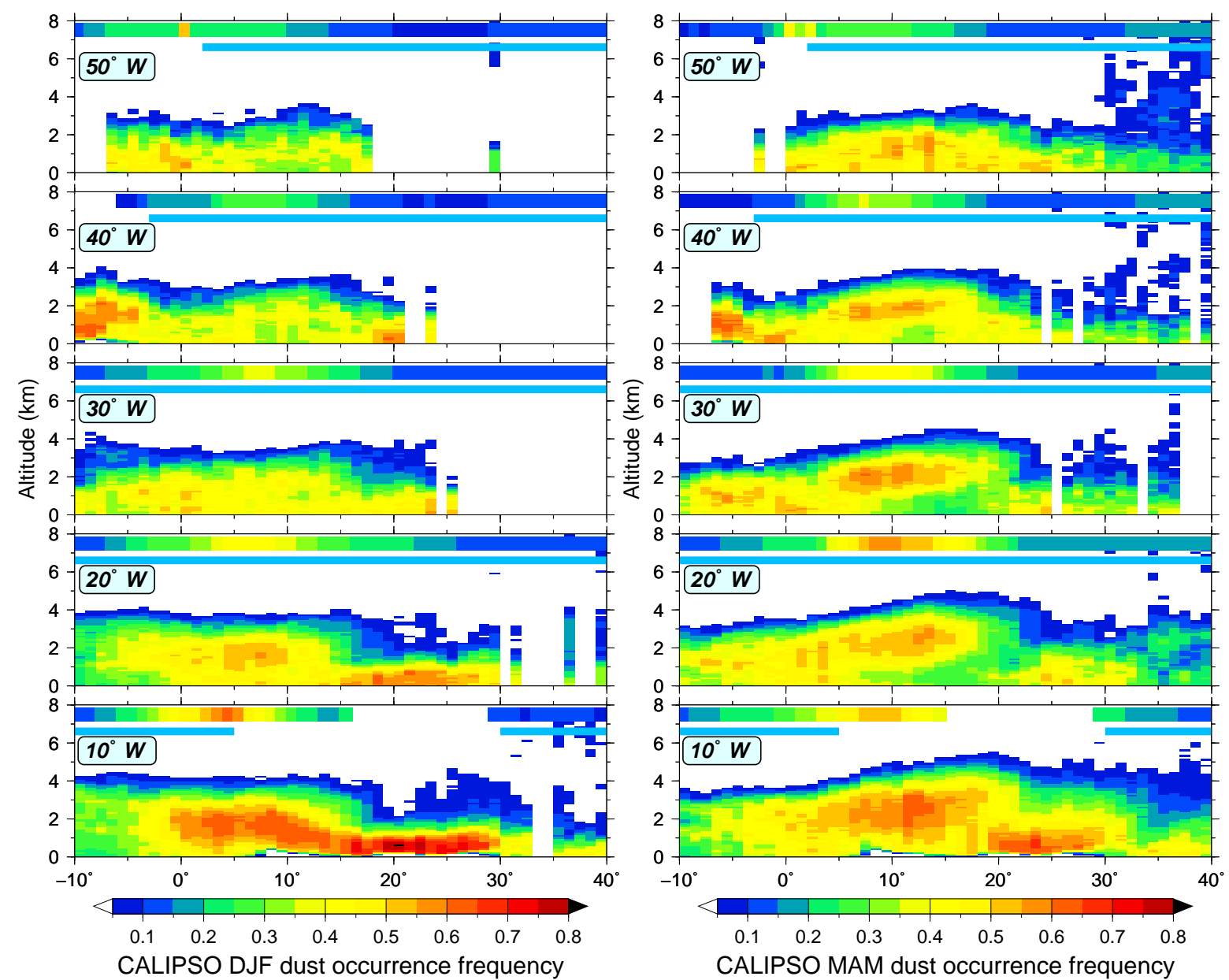

Fig. 3. Vertical distribution of the dust aerosols occurrence frequency above the Atlantic Ocean at five longitudes $\left(10,20,30,40\right.$ and $\left.50^{\circ} \mathrm{W}\right)$ during winter (DJF - left) and spring (MAM - right) seasons from $5 \mathrm{yr}$ of CALIPSO observations. The abscissa is the latitude from $10^{\circ} \mathrm{S}$ to $40^{\circ} \mathrm{N}$. The cyan line at $6.5 \mathrm{~km}$ of each cross section marks the ocean, while the color line above it, between 7 and $8 \mathrm{~km}$, is the MODIS AOD at $550 \mathrm{~nm}$. The colorbar of MODIS AOD is the same as that of the dust occurrence frequency.

as well as more elevated, occupying a thicker layer during summer.

For completeness and in order to provide the spatial extension of the SAL as seen from CALIPSO, the DOF at six vertical levels from CALIPSO for the four seasons can be found in the Appendix (Figs. A1-A4). The six levels are $1 \mathrm{~km}$ (bottom left), $2 \mathrm{~km}$ (middle left), $3 \mathrm{~km}$ (top left), $3.5 \mathrm{~km}$ (bottom right), $4.2 \mathrm{~km}$ (middle right) and $4.8 \mathrm{~km}$ (top right). These levels have been chosen in order to offer a good vertical description of the SAL and to match the existing pressure levels of the ECMWF wind data (at 900, 800, 700, 650, 600 and $550 \mathrm{hPa}$ ), which will be used in the next section. Also, the wind direction from ECMWF at these pressure levels is denoted by the black vectors, while the wind speed is given by the magenta isolines. It must be mentioned that for these figures no averaging or smoothing has been applied to CALIPSO results.
The SAL is located by using the thresholds for DOF of 0.35 and for AOD of $0.2-0.25$. The DOF being a relative magnitude is held constant for the whole region of interest, whereas the AOD is an absolute magnitude and its decrease with westward transport (e.g., Kalashnikova and Kahn, 2008) has been taken into account by applying a threshold of 0.25 close to Africa and 0.2 close to the Americas. These thresholds are arbitrary, but they have been chosen by taking into account that away from the Sahara and the main part of the SAL the DOF can take values up to 0.3 and the AOD up to 0.2. For comparison, the Maritime Aerosol Network (MAN) for the Atlantic indicated that $75 \%$ of the data have AOD at $500 \mathrm{~nm}$ values less than 0.2 (Smirnov et al., 2011, see also their Fig. 3a). 


\subsection{Winter (DJF)}

During winter (Fig. 3, left), SAL is found within $5^{\circ} \mathrm{S}-15^{\circ} \mathrm{N}$ off western Africa (taking DOF $>0.35$ ), while close to the coast of South America it is observed within $5^{\circ} \mathrm{S}-10^{\circ} \mathrm{N}$. This is in agreement with MODIS AOD shown at the top of each cross section (taking AOD > 0.25) and with the results of Huang et al. (2010). The dust aerosols detected close to Africa $\left(10\right.$ to $\left.30^{\circ} \mathrm{W}\right)$ north of $15^{\circ} \mathrm{N}$ and below $1.5 \mathrm{~km}$ are not part of the SAL, as will be demonstrated by its seasonal evolution below and the wind fields in the next section. Vertically, SAL is observed between the surface and $3 \mathrm{~km}$ close to Africa, while its top goes down to about $2 \mathrm{~km}$ by the time it reaches South America. The SAL signature can be observed till $60^{\circ} \mathrm{W}$ (Figs. 2 and A1) with the top at the same level. Close to Africa $\left(20^{\circ} \mathrm{W}\right)$, the maximum DOF is 0.6 , found at $2 \mathrm{~km}$ collocated with the AOD maximum in the interval 5$10^{\circ} \mathrm{N}$. Above South America $\left(50^{\circ} \mathrm{W}\right)$, the maximum DOF $(>0.5)$ is located at $0.5 \mathrm{~km}$ near the Equator.

South of $10^{\circ} \mathrm{N}$, the biomass burning aerosols emitted during this period of the year are mixed with desert dust (Haywood et al., 2008). The important number of dust layers seen to the south of $5^{\circ} \mathrm{N}$ (Fig. 2) is mostly due to the inclusion of the polluted dust class in the analysis, even if this inclusion does not impact on the results. In fact, taking into account only the desert dust class of CALIPSO and not the combination of desert dust and polluted dust does not change the vertical distribution of DOF in Fig. 3 (left) (not shown). Thus, the inclusion of the polluted dust class in the analysis does not modify the results for this region during winter. This can be explained by the fact that CALIPSO classifies the aerosol layers with relatively high estimated particulate depolarization ratio $(>0.2)$ as desert dust (Omar et al., 2009), which can comprise also dust and smoke mixtures. Indeed, lidar measurements above Cape Verde observed aerosol mixtures of biomass burning and desert dust having wavelengthindependent depolarization ratios between 0.12 and 0.23 (Gross et al., 2011; Tesche et al., 2011; Weinzierl et al., 2011). At $40^{\circ} \mathrm{W}$, over South America it can be noticed that DOF takes relatively high values $(>0.5)$ from the surface up to $2 \mathrm{~km}$. However, they are not part of the SAL as they are observed south of $5^{\circ} \mathrm{S}$ (also notice that MODIS AOD is lower than 0.05). The elevated DOF values could be related to the lower number of detected dust layers above South America $(<300)$ than over the nearby ocean (Fig. 2). It should be mentioned that the majority of dust layers detected over South America south of the Equator from CALIPSO are polluted dust (not shown). Although the contamination from local biomass burning aerosols cannot be totally excluded, the fire activity to the north and east of the Amazon Basin peaks in fall (van der Werf et al., 2003; Giglio et al., 2006), meaning that the majority of these layers are transported from Africa (Ansmann et al., 2009; Baars et al., 2011).

Near the African coast, measurements from recent campaigns during winter indicated a two-layer aerosol struc- ture with desert dust up to $1.5-2 \mathrm{~km}$ and mixed dust/smoke aerosols above reaching an altitude of $5 \mathrm{~km}$ (Johnson et al., 2008; McConnell et al., 2008; Tesche et al., 2011). Other studies, based on CALIPSO data, reported dust top height at about $3 \mathrm{~km}$ near the African coast $\left(10-20^{\circ} \mathrm{W}\right)$ (Ben-Ami et al., 2009; Huang et al., 2010), in agreement with our results. As mentioned previously, this difference between CALIPSO and the field studies can be explained by the use of different ways (and instruments) to characterize a layer as desert dust and to separate it from other aerosol types. It should be noted that mineral dust is also found even in aged elevated biomass burning layers over western Africa (at least north of $8^{\circ} \mathrm{N}$ ), accounting for $72 \%$ of the estimated aerosol mass (Formenti et al., 2008). Over the Atlantic, a shipborne campaign found dust maximum height just above $2 \mathrm{~km}$ around $40^{\circ} \mathrm{W}$ (Voss et al., 2001), which is in agreement with Fig. 3 (left). Further away, above South America, two studies reported Saharan dust below about $3 \mathrm{~km}$, mostly well mixed with smoke (Ben-Ami et al., 2010; Baars et al., 2011). The Saharan dust aerosols fertilize the Amazon Basin during winter, which is very important for the maintenance of its nutrition balance (Kaufman et al., 2005; Koren et al., 2006); they also act as ice nuclei, thereby influencing precipitation and radiation budget of the Amazon's sensitive ecosystem (Prenni et al., 2009). Although Ben-Ami et al. (2010) have presented a case study of this transport, here a more general and complete picture is given using climatological data. However, there is still need of independent studies to further validate our results, especially over the Amazon.

\subsection{Spring (MAM)}

Figure 3 (right) displays the results for spring. It can be observed that SAL moves $5^{\circ}$ northwards both off western Africa $\left(0-20^{\circ} \mathrm{N}\right)$ and off South America $\left(0-15^{\circ} \mathrm{N}\right)$, although the number of dust layers is reduced south of $5^{\circ} \mathrm{N}$ (Fig. 2). CALIPSO results are in accordance with MODIS observations close to Africa, while off South America, although DOF values do not seem to decrease significantly north of $15^{\circ} \mathrm{N}$, the number of dust layers is reduced to less than 500 (Fig. 2). This shows both the weakness of DOF as it does not provide any information about the dust load and the usefulness of coupling DOF with MODIS AOD and the number of dust layers provided from CALIPSO. Also, north of $20^{\circ} \mathrm{N}$, dust layers can be observed scattered over the entire North Atlantic, in contrast to the other seasons (Fig. 2), although their number is less than 300 . These can be either dust mixed with anthropogenic pollution from North America or desert dust transported from Asia (e.g., Uno et al., 2009). Although the possibility of dust from the Sahara cannot be excluded, the wind pattern seen in Fig. A2 makes it less probable. Over the eastern Atlantic, SAL occurs in the altitude range 1$4 \mathrm{~km}$ for its northern part $\left(10-20^{\circ} \mathrm{N}\right)$ and between the surface and $3 \mathrm{~km}$ for its southern part $\left(0-10^{\circ} \mathrm{N}\right)$. The higher altitude range at the northern part of SAL (Fig. 3 (right) at 20 

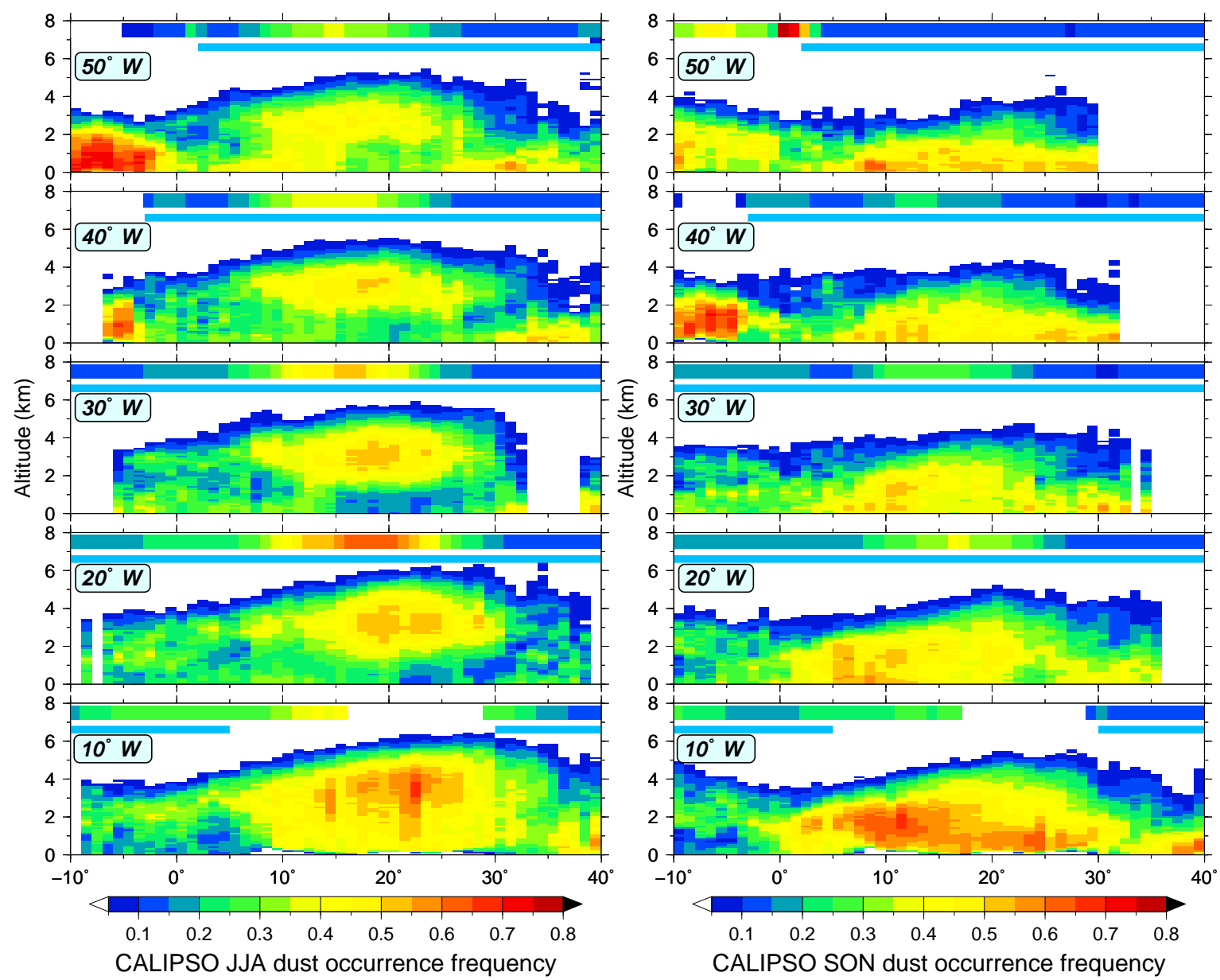

Fig. 4. Same as Fig. 3 but for summer (JJA - left) and fall (SON - right) seasons.

and $30^{\circ} \mathrm{W}$ ) results from the influence of the trade winds, as shown in the next section. Its maximum altitude is reached at about $14^{\circ} \mathrm{N}$, which is $5^{\circ}$ north of the AOD maximum. The maximum DOF of 0.6 is found at $2-3 \mathrm{~km}$, below the maximum altitude $\left(14^{\circ} \mathrm{N}\right)$. Towards South America (and the south Caribbean Sea for this season) SAL lies between the surface and $2-2.5 \mathrm{~km}$, while the maximum DOF $(\sim 0.55)$ is found around $10^{\circ} \mathrm{N}$ at $1.5 \mathrm{~km}$. It can be detected as far as $70^{\circ} \mathrm{W}$ around $10^{\circ} \mathrm{N}$ (Figs. 2 and $\mathrm{A} 2$ ) at the same altitude range (not shown). In the same figures one can notice dust layers beyond $70^{\circ} \mathrm{W}$; however in northern South America, spring is the season with the most fire activity (van der Werf et al., 2003; Giglio et al., 2006). Thus, results westward of $60^{\circ} \mathrm{W}$ over land should be used and interpreted with caution, keeping in mind that the majority of dust layers there (Fig. 2) belong to the polluted dust class (not shown). Like in winter, at $40^{\circ} \mathrm{W}$ over eastern South America (Fig. 3, right) relatively high DOF values can been seen below $2 \mathrm{~km}$. However, this is not part of SAL and the number of dust layers there is limited (Fig. 2).
Analysis of 3 yr of observations over a coastal site of Senegal (Leon et al., 2009), indicated that the dust layer top is located a little higher between 4 and $5 \mathrm{~km}$ during spring than what we found in this study. On the other hand, over northeastern South America, Formenti et al. (2001) found that dust layers extended up to $700 \mathrm{hPa}(\sim 3 \mathrm{~km})$. These last results are in agreement with Fig. 3 (right). Despite the fact that the dust transport to northern South America peaks in spring (Prospero et al., 1981), studies on the vertical distribution of dust in both sides of the Atlantic during this season are sparse.

\subsection{Summer (JJA)}

Although the characteristic oval shape of SAL (Karyampudi et al., 1999; Liu et al., 2008b) starts to appear at its northern part during spring, it can be more clearly observed during summer (Fig. 4, left). In summer, SAL moves farther northward, occurring off western Africa between 5 and $30^{\circ} \mathrm{N}$ and between 10 and $25^{\circ} \mathrm{N}$ east of the Caribbean Sea, and reaching Central America, the southeastern USA and the Gulf of Mexico (Figs. 2, 5 and A3). Also, the northern edge of SAL 


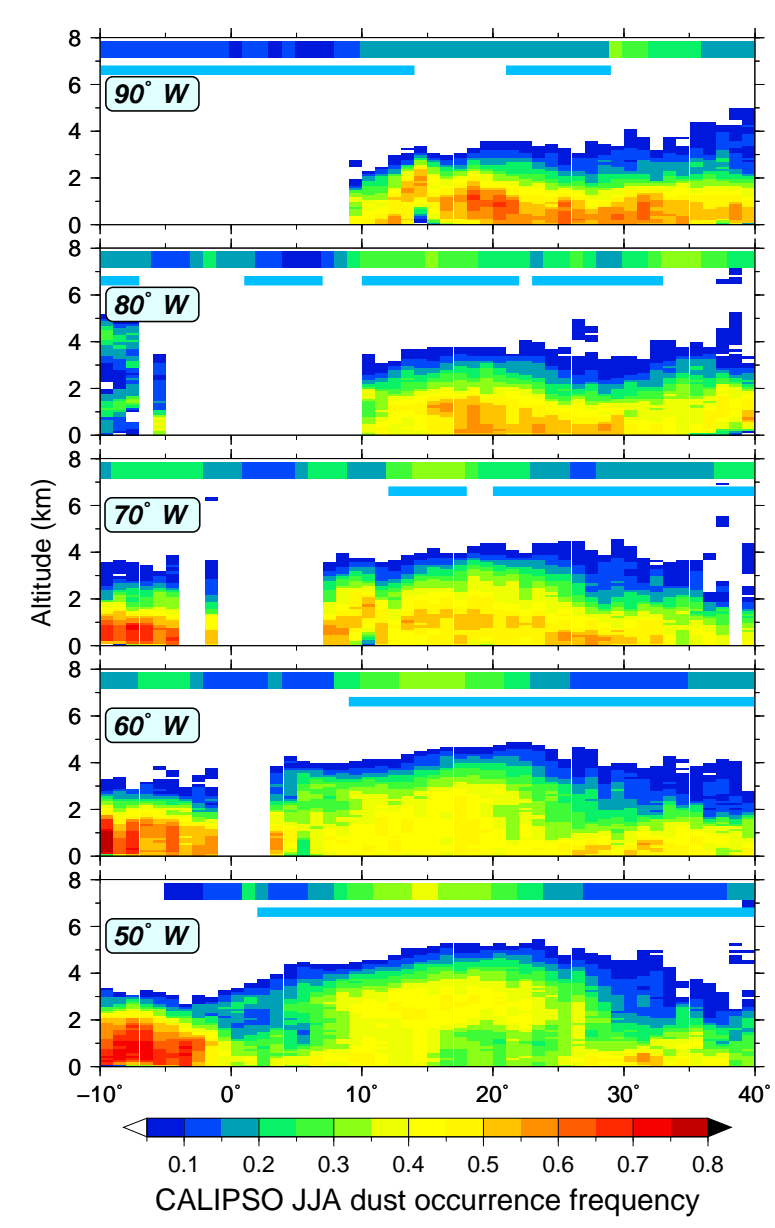

Fig. 5. Same as Fig. 3 but only for summer (JJA) at the five longitudes: $50,60,70,80$ and $90^{\circ} \mathrm{W}$. The cross section at $50^{\circ} \mathrm{W}$ is repeated in order to facilitate the inspection of SAL evolution.

moves southwards till $50^{\circ} \mathrm{W}$ reaching $25^{\circ} \mathrm{N}$, and then starts to turn northwards (Figs. 2, 4 (left) and 5), which is in accordance with the anticyclonic rotation of the SAL within the ridge region mentioned by Karyampudi et al. (1999). This is not obvious from the MODIS AOD 0.25 isoline in Fig. 2, but it can be observed from the AOD plotted at the top of each cross section of Figs. 4 (left) and 5. The comparison between winter and summer in Fig. 2 depicts clearly the seasonal latitudinal displacement of SAL and the longer westward transport of dust during summer. Near Africa, SAL lies in the altitude range 1 to $5 \mathrm{~km}$, with its maximum top at about $21^{\circ} \mathrm{N}$ when the AOD maximum is found at $\sim 17^{\circ} \mathrm{N}$, as in spring. This meridional shift between the maximum AOD and altitude observed in both seasons can be explained by the lower DOF, which indicates a lower amount of dust aerosols, below the northern part of SAL in comparison to the southern one. A similar meridional shift was found between the maximum dust AOD and the temperature difference induced by dust outbreaks (Wilcox et al., 2010). At the
mid-Atlantic $\left(30-40^{\circ} \mathrm{W}\right)$ the base of SAL increases to $1.5-$ $2 \mathrm{~km}$ (more evident for the southern part of SAL), while the top decreases with westward transport, as for the other seasons. Around $50^{\circ} \mathrm{W}$, a transition is seen with SAL presenting two parts: the southern one $\left(10-15^{\circ} \mathrm{N}\right)$, found between the surface and $3.5 \mathrm{~km}$, and the northern one $\left(15-25^{\circ} \mathrm{N}\right)$, between 1.5 and $4 \mathrm{~km}$ (Fig. 4, left). Again, this seems to be a result of the influence of the trade winds (examined in the next section). After $60^{\circ} \mathrm{W}$, the SAL bottom appears to be in contact with the surface, while the top continues to decrease, reaching $2 \mathrm{~km}$ at $80^{\circ} \mathrm{W}$ (Fig. 5). The maximum DOF ( $>0.5$ ) is found about $3 \mathrm{~km}$ off western Africa $\left(20^{\circ} \mathrm{W}\right)$ between 15 and $25^{\circ} \mathrm{N}$, decreasing to below $1 \mathrm{~km}$ at $80^{\circ} \mathrm{W}$ around $20^{\circ} \mathrm{N}$. The maximum DOF appears to be collocated with the maximum warming of the SAL found at 2-3 km (Wang, 2009), especially over the eastern Atlantic. Further west, the signature of the SAL is less clear as MODIS AOD is below 0.2, although CALIPSO sees dust layers below $2 \mathrm{~km}$.

The high values of DOF ( $>0.6$ ) south of the Equator over South America are not related at all to dust aerosols from Africa, as can been seen from the wind direction in Fig. A3. The dust layers seen there belong to the polluted dust class (not shown), while their origin could be attributed to the transport of biomass burning aerosols from fires in the Amazon Basin during late summer (Giglio et al., 2006). In the previous section, we noticed differences between CALIPSO's number of dust layers and MODIS AOD north of $20^{\circ} \mathrm{N}$, close to North America (Fig. 2). This discrepancy is reduced by taking the 0.2 AOD isoline, which is found $2-3^{\circ}$ northward of the $0.25 \mathrm{AOD}$ isoline. The significant number of dust layers north of $23^{\circ} \mathrm{N}$ can be attributed to anticyclonic circulation observed close to $30^{\circ} \mathrm{N}$ and $50^{\circ} \mathrm{W}$ (Fig. A3). Indeed, the wind vectors in Fig. A3 indicate that a contamination of dust aerosols with North American pollution is unlikely. On the other hand, the dust aerosols north of $20^{\circ} \mathrm{N}$ can be entrapped in the anticyclonic circulation, and thus either deposited at the mid-Atlantic or dispersed during the transport, therefore decreasing their AOD. This can explain the discrepancy between MODIS AOD and CALIPSO's number of dust layers.

In contrast with the other seasons, there are more observations of SAL during summer, and especially in the eastern Atlantic. Above Cape Verde, measurements of the SAMUM$2 \mathrm{~b}$ campaign indicate that the dust layer top is at $4.4 \pm 0.7 \mathrm{~km}$ with a mean layer depth of $4.1 \pm 0.7 \mathrm{~km}$, above a $0.5-1.0 \mathrm{~km}$ deep maritime boundary layer (Tesche et al., 2011). Airborne measurements near Dakar above ocean registered dust up to $6 \mathrm{~km}$ (McConnell et al., 2008). Off western Africa, NAMMA airborne observations pointed out that the SAL generally extends up to 4 to $6.5 \mathrm{~km}$, with a characteristic temperature inversion at its base at about $2 \mathrm{~km}$ (Ismail et al., 2010), which agrees with shipborne lidar measurements in the same region (Immler and Schrems, 2003). Also, SAGE II climatological data reveal one dust layer in the eastern north tropical Atlantic located between 2 and $6 \mathrm{~km}$ (Zhu et al., 2007). On the 


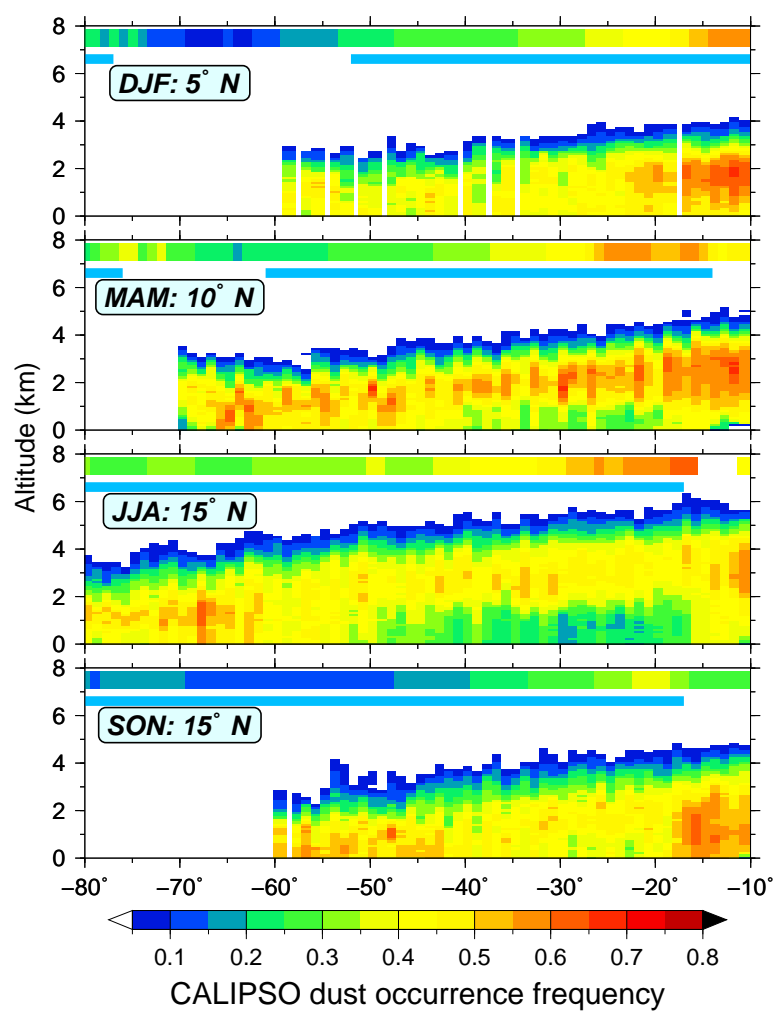

Fig. 6. Vertical distribution of the dust aerosols occurrence frequency above the Atlantic Ocean (from top to bottom) during winter $\left(\mathrm{DJF}\right.$ at $\left.5^{\circ} \mathrm{N}\right)$, spring $\left(\mathrm{MAM}\right.$ at $\left.10^{\circ} \mathrm{N}\right)$, summer $\left(\mathrm{JJA}\right.$ at $\left.15^{\circ} \mathrm{N}\right)$ and fall $\left(\mathrm{SON}\right.$ at $\left.15^{\circ} \mathrm{N}\right)$. The abscissa is the longitude from 80 to $10^{\circ} \mathrm{W}$. The cyan line at $6.5 \mathrm{~km}$ of each cross section marks the ocean, while the color line above it, between 7 and $8 \mathrm{~km}$, is the MODIS AOD at $550 \mathrm{~nm}$. The colorbar of MODIS AOD is the same as that of the dust occurrence frequency.

west side of the Atlantic, results from the PRIDE campaign indicate that dust aerosols can reach an altitude of $5 \mathrm{~km}$, presenting a highly variable vertical distribution and revealing the presence of dust in the marine boundary layer at Puerto Rico (Reid et al., 2002, 2003). Similar results were reported over Florida with case studies of dust layers from 1 to $4 \mathrm{~km}$ (DeMott et al., 2003) and from 1.7 to $5.5 \mathrm{~km}$ (Sassen et al., 2003). According to this study, in the area of Puerto Rico $\left(20^{\circ} \mathrm{N}, 60-70^{\circ} \mathrm{W}\right)$, the dust layer is found mostly below $3 \mathrm{~km}$, although some dust can be observed up to $4.5-5 \mathrm{~km}$ (DOF 0.1) (Fig. 5).

\subsection{Fall (SON)}

Finally, during fall (Fig. 4, right), SAL turns back southward, lying between 0 and $25^{\circ} \mathrm{N}$ off western Africa and between 5 and $20^{\circ} \mathrm{N}$ at $50^{\circ} \mathrm{W}$, taking into account also the MODIS AOD and the number of dust layers from CALIPSO. In the vertical, dust aerosols are found between the surface and $3 \mathrm{~km}$ close to Africa, while east of the Caribbean Sea, the top decreases to $2 \mathrm{~km}$. However, west of $40^{\circ} \mathrm{W}$, MODIS AOD is close to 0.1 , a typical value for remote maritime regions (Smirnov et al., 2011), thus indicating the absence of a significant dust load farther west. On the other hand, CALIPSO DOF does not present any obvious change, although the available number of dust layers is reduced (Fig. 2). This manifests the limits of the DOF, which does not permit for a quantitative description of the dust load, and renders the position of the northern border of SAL above the mid-Atlantic less accurate during this season. Also, there is neither an obvious maximum of DOF close to Africa nor close to the Caribbean Sea. The high DOF values at $40^{\circ} \mathrm{W}$ above South America can rather be linked to fire activity, which peaks in fall (van der Werf et al., 2003; Giglio et al., 2006), confirmed by the wind direction in Fig. A4. Leon et al. (2009) reported a layer between 1 and $2 \mathrm{~km}$ above a coastal site in Senegal; their results also indicated that there is significant interannual variability with aerosols from the surface up to $3-4 \mathrm{~km}$ during some years. It should be underlined that the lack of studies during this season is partly due to the less strong dust outbreaks (Ben-Ami et al., 2012).

\subsection{Zonal evolution of the SAL characteristics}

As the spatial extension of the SAL and its limits are described previously, we focus now on its zonal evolution above the Atlantic. Figure 6 presents the vertical distribution of CALIPSO DOF at one longitude for each season at $5^{\circ} \mathrm{N}$ for winter, $10^{\circ} \mathrm{N}$ for spring and $15^{\circ} \mathrm{N}$ for summer and fall. As SAL shifts latitudinally during the different seasons, the latitudes have been chosen in order to be representative of the central part of SAL during each season. Figure 6 is similar to Figs. 3 and 4, but in this case the horizontal axis is the longitude from 10 to $80^{\circ} \mathrm{W}$. Data after $60^{\circ} \mathrm{W}$ for winter and fall or after $70^{\circ} \mathrm{W}$ for spring have been removed because of the limited number of dust layers (Fig. 2).

It can be observed that the altitude decrease of SAL with westward transport is smooth for all seasons. Once SAL leaves Africa, it is found in contact with the ocean surface during winter and fall. In contrast, during spring its base is found at $1 \mathrm{~km}$ from 20 to $40^{\circ} \mathrm{W}$. This is also the case in summer, with the base located at $1.5 \mathrm{~km}$ between 15 and $50^{\circ} \mathrm{W}$, while from 20 to $30^{\circ} \mathrm{W}$ the DOF is lower than 0.2. Figure 6 further corroborates the results seen in Figs. 3 (right) and 4 (left) for spring and summer, with lower DOF values below the SAL (especially its northern part) at the eastern Atlantic. At the top of each cross section, a decrease of MODIS AOD with westward transport can be seen, while the DOF values do not seem to change significantly (although higher DOF values are found over Africa). This underlies the difference between the use of relative and absolute magnitudes in the description of the SAL evolution.

Figures 3, 4 and 6 indicate that the SAL is not characterized by a multilayer structure, but rather it can be described by a single layer (at least climatologically). This is 

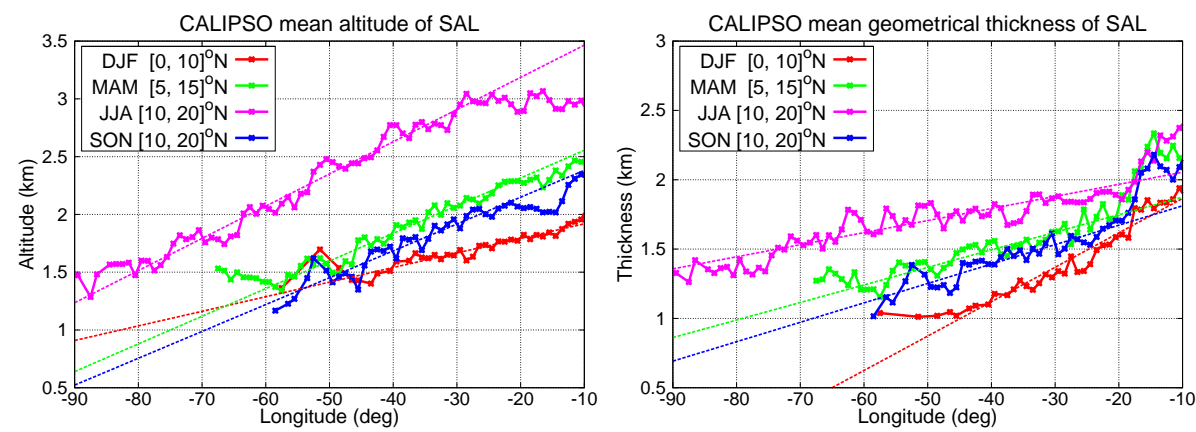

Fig. 7. Mean zonal evolution of SAL altitude (left) and geometrical thickness (right) based on CALIPSO data from Africa ( $-10^{\circ}$ E) to the Americas $\left(-90^{\circ} \mathrm{E}\right)$. Each point is an average over $10^{\circ}$ in latitude (indicated in the legend) depicting the mainly position of SAL in every season. The dotted lines are the linear fits for every season (see text for details).

in agreement with the climatology of SAGE II off western Africa during summer (Zhu et al., 2007) (a second dust layer below $1 \mathrm{~km}$ seen in their Fig. 7 can be explained by the transport of dust at lower levels during the rest of the year). BenAmi et al. (2009), on the other hand, using the first year of CALIPSO data, noticed a two-layer structure of dust above the Atlantic especially during summer, with the lower one attached or within the marine boundary layer. This is no longer found here. In Fig. 4 (left) south of $20^{\circ} \mathrm{N}$, it can be observed that below $1.5 \mathrm{~km}$ there are indeed dust aerosols $(\mathrm{DOF}=0.2-0.3)$, although below the SAL. The picture of the SAL as a single layer is also in agreement with the studies of Karyampudi et al. (1999), Liu et al. (2008b), Ben-Ami et al. (2010), Braun (2010) and Adams et al. (2012), as well as with the example in Fig. 1. Thus, the use of notions like mean altitude and mean geometrical thickness are adequate to describe it.

Figure 7 presents the mean altitude (a.s.l.) and geometrical thickness, averaged over $10^{\circ}$ in latitude, for the four seasons between Africa $\left(10^{\circ} \mathrm{W}\right)$ and the Americas $\left(90^{\circ} \mathrm{W}\right)$. The mean altitude and the mean geometrical thickness of the SAL are calculated from the respective vertical frequency distribution at each bin in latitude and longitude, between the surface and the altitude of $7 \mathrm{~km}$, and then averaged to $10^{\circ}$ latitudinal zones for every $1^{\circ}$ in longitude. The choice of a maximum altitude of $7 \mathrm{~km}$ for the exploration range comes from the results of previous sections, based on Figs. $3-6$. The $10^{\circ}$ zone is different among the four seasons in order to depict the central part of the SAL during its westward transport. Although during spring and fall there are few data after 70 and $60^{\circ} \mathrm{W}$, respectively, these have been removed because of the limited number of detected dust layers. The thin dotted lines are the linear fit in the interval $10-50^{\circ} \mathrm{W}$ for winter, $20-60^{\circ} \mathrm{W}$ for spring and fall and $30-80^{\circ} \mathrm{W}$ for summer. It should be kept in mind that the results after $60^{\circ} \mathrm{W}$ in spring are less reliable due to the peak of fire activity in northern South America.

Figure 7 indicates that there is a clear distinction between winter and summer both for the altitude (left) and the geometrical thickness (right) with higher values during sum- mer. The transition seasons of spring and fall show similar characteristics with the values of altitude and geometrical thickness bounded by the respective values of winter and summer. Both mean altitude and geometrical thickness decrease from Africa to the Americas, except altitude during summer, which stays approximately constant at $3 \mathrm{~km}$ up to $30^{\circ} \mathrm{W}$ and then decreases. The SAL mean altitude decreases with westward transport by $13 \mathrm{~m} \mathrm{deg}^{-1}$ in winter, $24 \mathrm{~m} \mathrm{deg}^{-1}$ in spring and $23 \mathrm{~m} \mathrm{deg}^{-1}$ in fall (with the mean altitude being $200 \mathrm{~m}$ higher during spring) and $28 \mathrm{~m} \mathrm{deg}^{-1}$ in summer. Ben-Ami et al. (2009) used the first year of CALIPSO data and found that the top altitude decreases by $23 \mathrm{~m} \mathrm{deg}^{-1}$ in winter (about twice than our results) and $27 \mathrm{~m} \mathrm{deg}^{-1}$ in summer (similar with our results). The SAL mean geometrical thickness also regularly decreases, but with higher rates in winter than in summer (contrary to altitude), while spring and fall have similar rates. Between 10 and $20^{\circ} \mathrm{W}$, SAL geometrical thickness reduces sharply, due to the transition from land to ocean, except during winter, when the central part of $\mathrm{SAL}$ is mostly above ocean. The decrease rate is $25 \mathrm{~m} \mathrm{deg}^{-1}$ in winter, $13 \mathrm{~m} \mathrm{deg}^{-1}$ in spring, $9 \mathrm{~m} \mathrm{deg}^{-1}$ in summer and $14 \mathrm{~m} \mathrm{deg}^{-1}$ in fall. The decrease of SAL altitude and geometrical thickness with westward transport can be attributed to the descent of the dust aerosols by sedimentation and largescale subsidence due to general circulation with wet removal modulating these processes (Colarco et al., 2003). On the other hand, the clear sky subsidence due to longwave radiative cooling - also depending on the water vapor content - is another factor contributing to the observed decrease (Huang et al., 2010).

Results of SAL mean altitude and its decrease with westward transport (Fig. 7), which is linear at first order, coupled to the mean wind speed (Figs. A1-A4) allow for estimating the effective dry deposition velocity (combining dynamical forcings and dry sedimentation) of dust particles. The estimation is based on the simple assumption that both the effective dry velocity and the wind speed can be thought as almost constant during the westward transport of the SAL. By using the equations $u_{\mathrm{d}}=\frac{\Delta Z_{\mathrm{SAL}}}{\Delta t}, u_{\mathrm{z}}=\frac{\Delta x}{\Delta t}$ and $\alpha=\frac{\Delta Z_{\mathrm{SAL}}}{\Delta x}$ 
we obtain

$u_{\mathrm{d}}=\alpha \cdot u_{\mathrm{z}}$

and its uncertainty, $\delta u_{\mathrm{d}}=\alpha \cdot \delta u_{\mathrm{z}}+u_{\mathrm{z}} \cdot \delta \alpha$, where $u_{\mathrm{d}}$ stands for the effective dry velocity, $u_{\mathrm{z}}$ is the mean zonal wind speed, $\Delta x$ and $\Delta Z_{\mathrm{SAL}}$ are the zonal and vertical displacements in the time period $\Delta t$ and $\alpha$ is the decrease of SAL mean altitude $\left(Z_{\mathrm{SAL}}\right)$ with the westward transport.

The mean altitude of SAL is between 1.5 and $2 \mathrm{~km}$ in winter, 1.5 and $2.5 \mathrm{~km}$ in spring and fall, and 1.5 and $3 \mathrm{~km}$ in summer (Fig. 7, left). These values correspond to pressure levels of about $800-850 \mathrm{hPa}$ in winter, $750-850 \mathrm{hPa}$ in spring and fall and $700-850 \mathrm{hPa}$ in summer. At these pressure levels the mean wind speed from ECMWF (for the same zones as for the mean altitude) is $6.6 \mathrm{~m} \mathrm{~s}^{-1}$ in winter (longitudinal range: $5.5-8.5 \mathrm{~m} \mathrm{~s}^{-1}$ ), $6.6 \mathrm{~m} \mathrm{~s}^{-1}$ in spring (longitudinal range: $6-8 \mathrm{~ms}^{-1}$ ), $8 \mathrm{~ms}^{-1}$ in summer (longitudinal range: $7.5-8.5 \mathrm{~m} \mathrm{~s}^{-1}$ ) and $5.2 \mathrm{~m} \mathrm{~s}^{-1}$ in fall (longitudinal range: $5-5.5 \mathrm{~m} \mathrm{~s}^{-1}$ ) (for wind speed at 700 and $800 \mathrm{hPa}$ see Figs. A1-A4 and also Fig. 9 (left) of the next section). By taking $1^{\circ}$ of longitude to be equal to about $110 \mathrm{~km}$ near the Equator, this means that $1^{\circ}$ is covered in about $5 \mathrm{~h}$ for wind speed of $6 \mathrm{~ms}^{-1}$. In the same time period, the SAL mean altitude decreases with the values mentioned in the previous paragraph. Thus, after accounting for the average seasonal wind speed and applying Eq. (2), the effective dry deposition velocity of dust particles is $0.07 \pm 0.04 \mathrm{~cm} \mathrm{~s}^{-1}$ in winter, $0.14 \pm 0.05 \mathrm{~cm} \mathrm{~s}^{-1}$ in spring, $0.2 \pm 0.05 \mathrm{~cm} \mathrm{~s}^{-1}$ in summer and $0.11 \pm 0.04 \mathrm{~cm} \mathrm{~s}^{-1}$ in fall. Note that the summer effective dry deposition velocity is about 3 times the winter one.

The term effective is used here because the velocities are based on SAL mean altitude decrease and the wind speed from ECMWF, which account for all the processes relevant to the deposition of dust particles, like gravitational settling, turbulent mixing, Brownian diffusion, particle inertia, particle drag (Noll and Aluko, 2006; Foret et al., 2006) and the atmospheric subsidence. It should be noted that according to PRIDE observations, Stokes settling is too strong and an upward velocity is needed to account for the changes in dust particle size distribution (Maring et al., 2003). Generally, dry deposition velocities for dust particles based on collection of samples at the local scale have been estimated to be close to $1 \mathrm{cms}^{-1}$, with a possible range for a case study over Mediterranean between 0.1 and $6.9 \mathrm{~cm} \mathrm{~s}^{-1}$ depending on the used aerosol distribution for its calculation, which in turn is modulated by the contribution of large particles (Dulac et al., 1992). Our results lie within this range. Prospero et al. (2010) reported dry deposition velocities for different stations over Florida in the range $0.23-0.89 \mathrm{~cm} \mathrm{~s}^{-1}$ during summer, with their "best" stations yielding very similar values of 0.23 and $0.30 \mathrm{~cm} \mathrm{~s}^{-1}$. These values are in accordance with our results. However, for winter months they found very large deposition velocities in the range $1.30-3.13 \mathrm{cms}^{-1}$ (with their "best" stations yielding values of 1.30 and $1.72 \mathrm{~cm} \mathrm{~s}^{-1}$ ), which are much higher than our results. In addition, their winter results are higher than the summer ones, which is in contrast with our findings. It should be noted that during winter Florida is not in the main pathway of SAL (Sect. 3.1), and it is possible that their results either are affected by local dust sources or reflect a limited number of Saharan dust outbreaks reaching Florida during winter. Furthermore, our estimation considers spatial analysis, which includes larger scale dynamical forcings - and thus it may be different than local ones - estimated from time analysis. In any case there are not readily implemented techniques to measure dust deposition to the ocean (Prospero et al., 2010) and this is the reason for the limited number of observation studies dealing with dry deposition velocity and consequently its relatively high uncertainties. Thus, further studies are needed at several locations, especially during the winter period close to northern South America.

\section{Impact of wind on SAL shape}

Once the vertical distribution of the SAL has been established and validated against observations from other studies, the next step is to examine the possible impact of the wind field on the SAL shape. Figures 8 and 9 present the seasonal horizontal wind from the ERA-Interim data averaged over the same period as CALIPSO observations at three pressure levels: 900 ( $\sim 1 \mathrm{~km}$, bottom), $700(\sim 3 \mathrm{~km}$, middle $)$ and $500 \mathrm{hPa}(\sim 5.5 \mathrm{~km}$, top). In order to facilitate the interpretation of the interaction between SAL and wind, the MODIS AOD isolines of 0.25 and 0.5 are plotted as indicative of the SAL location and dust load. To avoid any misinterpretation of the isolines above the Sahara, it should be kept in mind that MODIS (standard algorithm) does not provide results above deserts. As mentioned in the previous section, Figs. A1-A4 present the CALIPSO DOF at six levels with the wind direction and speed from ECMWF, and they are supplementary to Figs. 8 and 9.

\subsection{Winter}

During winter, at low tropospheric levels $(900 \mathrm{hPa})$, the wind flow is northeasterly above the Equator bringing dust from Africa to South America (Fig. 8, left). However, away from the SAL, it can be observed that north of $25^{\circ} \mathrm{N}$ the wind direction changes from easterly to westerly due to highpressure systems located over the Atlantic between 20 and $30^{\circ} \mathrm{N}$ most of the year (Christopher and Jones, 2010). At $700 \mathrm{hPa}$, the wind in the eastern tropical Atlantic is easterly up to $15^{\circ} \mathrm{N}$ and then shifts to westerly, with the shift arriving now further south than the corresponding shift at $900 \mathrm{hPa}$. This change in the wind direction with altitude is observed in Fig. 3 (left) at $20^{\circ} \mathrm{W}$ with the quasi absence of dust aerosols north of $15^{\circ} \mathrm{N}$ above $2 \mathrm{~km}$ (as already mentioned, this latitude coincides with the northern border of the SAL during winter). The southern shift of the wind direction change with 

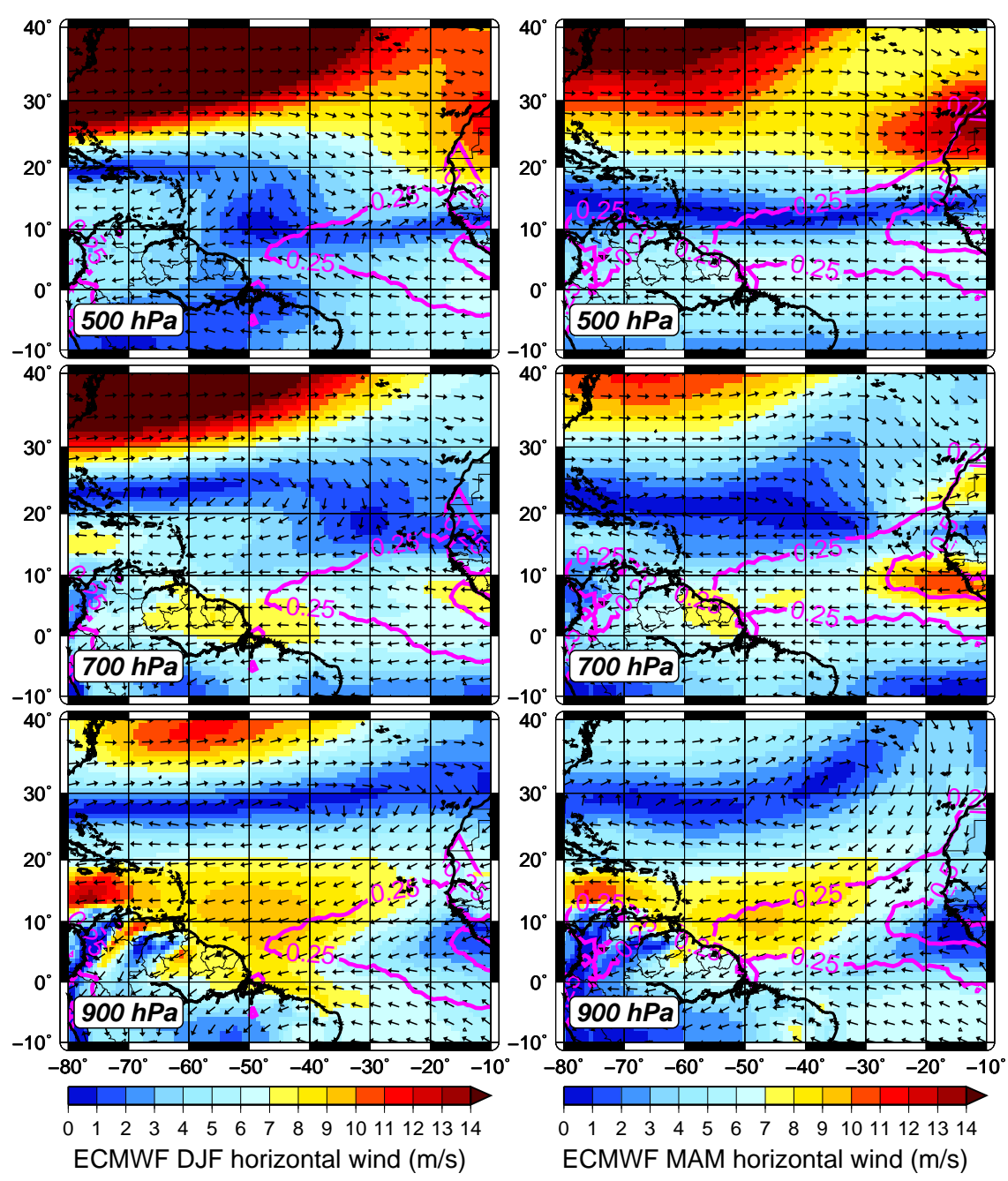

Fig. 8. Horizontal wind from ECMWF at three pressure levels ( $900 \mathrm{hPa}$ - bottom; $700 \mathrm{hPa}$ - middle; and $500 \mathrm{hPa}$ - top) during winter (DJF - left) and spring (MAM - right) seasons averaged over the same period as for CALIPSO. The vectors indicate the direction, and the color the wind speed $\left(\mathrm{ms}^{-1}\right)$. The magenta isolines of 0.25 and 0.5 depict the MODIS AOD at $550 \mathrm{~nm}$.

altitude can be discerned more easily in Fig. A1. No dust aerosols are seen at $500 \mathrm{hPa}$ in winter (see previous section). In agreement with these results, winter observations at Cape Verde indicate dust transport at low altitudes (below 1.5$3 \mathrm{~km}$ ) by the trade winds (Chiapello et al., 1995). Likewise, a regional model study shows dust transport up to $2-3 \mathrm{~km}$ within the trade wind layer (Schepanski et al., 2009).

\subsection{Spring}

Off western Africa at $900 \mathrm{hPa}$, the wind direction in spring is north-northeast, which brings mostly clean maritime air masses without dust aerosols from the North Atlantic down to $10-15^{\circ} \mathrm{N}$, while farther south, down to the Equator, the flow brings air masses from the Sahara (Fig. 8, right). This observation can explain the decrease of DOF at low lev- els seen in Fig. 3 (right) $\left(10-20^{\circ} \mathrm{N}, 20-40^{\circ} \mathrm{W}\right)$ and the DOF local minimum in the same region $(\mathrm{DOF}<0.35)$ observed in Fig. A2 at $900 \mathrm{hPa}$. Farther west, dust aerosols are found in contact with the surface due to the decrease of the SAL altitude with transport, while the relatively high speed $\left(>7 \mathrm{~m} \mathrm{~s}^{-1}\right)$ of dust-free air masses in the mid-Atlantic between 10 and $20^{\circ} \mathrm{N}$ (Fig. 8, right) delays the efficient mixing of the SAL dust aerosols inside the marine boundary layer westward of around $40^{\circ} \mathrm{W}$ (Fig. 3, right). At $700 \mathrm{hPa}$, there is a change of wind direction from easterly to westerly at about $20^{\circ} \mathrm{N}$, which does not permit for the development of SAL farther northwards at this altitude, thus confirming the horizontal extension of the SAL up to $20^{\circ} \mathrm{N}$ seen in the previous section. Although there are no dust aerosols at $500 \mathrm{hPa}$ during spring, it should be noted that at this level the change of wind direction happens south of $10^{\circ} \mathrm{N}$. This southern shift 

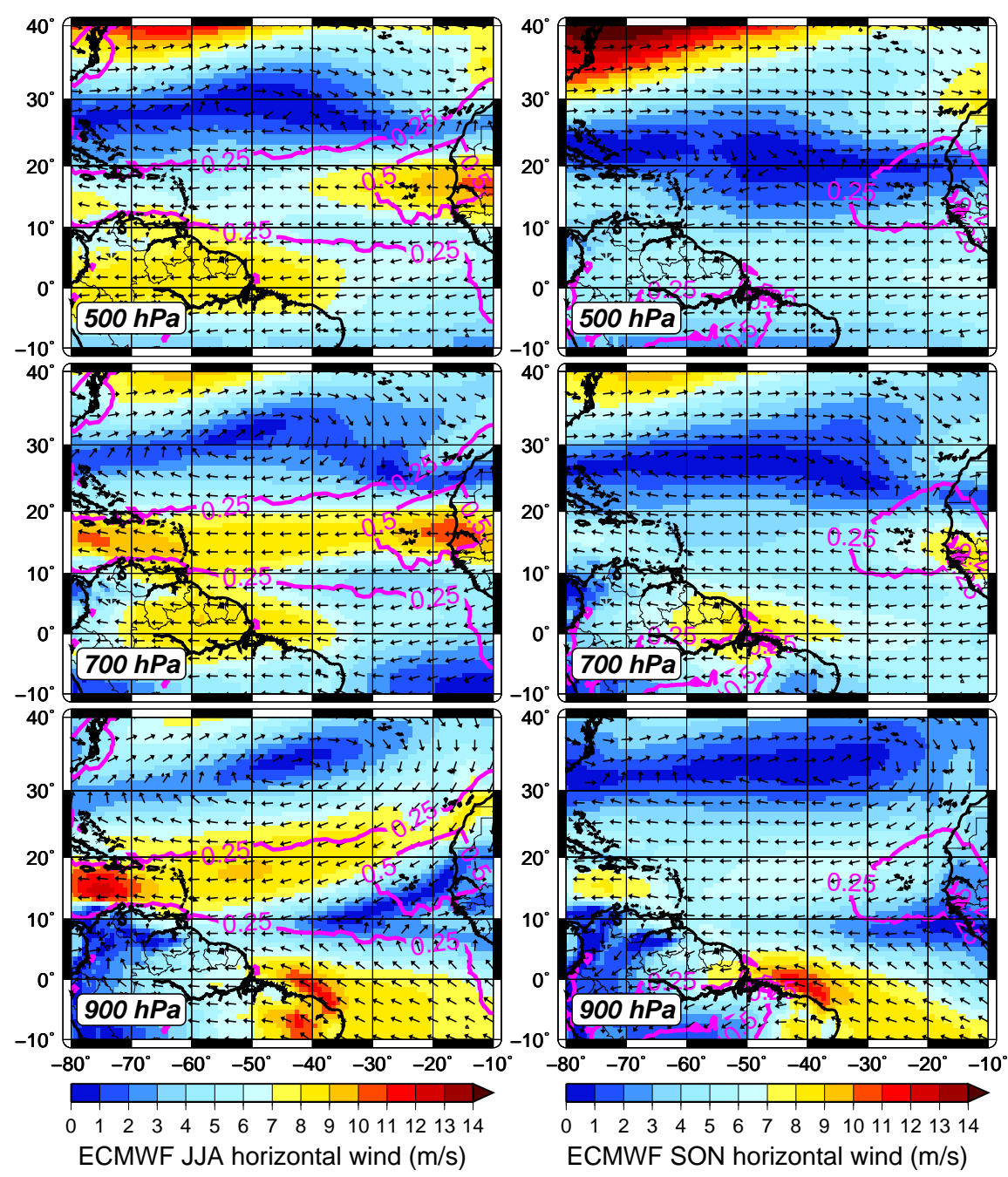

Fig. 9. Same as Fig. 8 but for summer (JJA - left) and fall (SON - right) seasons.

with altitude of the direction change can explain the ellipsoid shape on the northern part of the SAL seen in Fig. 3 (right).

\subsection{Summer}

At $900 \mathrm{hPa}$ during summer, the trade winds import clean air from both hemispheres below the SAL at least westward of $40^{\circ} \mathrm{W}$ (Figs. 9 (left) and A3). The high speed of the trade winds $\left(>7 \mathrm{~ms}^{-1}\right)$ prevents the efficient mixing of dust aerosols inside the marine boundary layer westward of $40^{\circ} \mathrm{W}$ for the southern part and up to $50^{\circ} \mathrm{W}$ for the northern part, in accordance with Fig. 4 (left). At $700 \mathrm{hPa}$, the flow is easterly up to about $30^{\circ} \mathrm{N}$, transporting the SAL directly to the Caribbean Sea, with strong wind $\left(>7 \mathrm{~m} \mathrm{~s}^{-1}\right)$ between 10 and $20^{\circ} \mathrm{N}$, where the maximum AOD of the SAL is seen (Fig. 4, left). After $60^{\circ} \mathrm{W}$, the flow turns to southeasterly, thus bringing dust aerosols to the southeastern USA and the Gulf of Mexico. At $500 \mathrm{hPa}$, the flow remains easterly up to $25^{\circ} \mathrm{N}$, while the wind magnitude is significant $\left(>7 \mathrm{~m} \mathrm{~s}^{-1}\right)$ westward of $40^{\circ} \mathrm{W}$, meaning a faster westward transport of dust aerosols at this altitude up to this longitude. As in spring, the oval shape seen in the northern edge of the SAL (Fig. 4, left) can be explained by the southern shift of wind direction change with altitude (depicted in Fig. A3). The role of relatively clean northeasterly trade winds that erode the lowlying dust aerosols of the SAL during the westward transport has also been noticed by previous studies (Karyampudi et al., 1999; Colarco et al., 2003). The wet removal can also be a contributing factor to dust erosion at low levels, while some of the low-level dust may persist all the way across the ocean (Colarco et al., 2003), as can be observed in Fig. 4 (left) (below SAL, DOF values 0.1-0.2). A model study showed as well that in summer, dust is transported above the trade winds inversion (Schepanski et al., 2009). 


\subsection{Fall}

During fall, at $900 \mathrm{hPa}$ the wind is mostly easterly (southeasterly below $\sim 5^{\circ} \mathrm{N}$ and northeasterly around $20^{\circ} \mathrm{N}$, Fig. 9 (right)). In Fig. 4 (right) at $20^{\circ} \mathrm{W}$ and about $25^{\circ} \mathrm{N}$, there is a minimum of DOF in relation with the transport of dust-free air masses from the north (see also Fig. A4). At $700 \mathrm{hPa}$, the flow is easterly up to $20-25^{\circ} \mathrm{N}$ and then changes direction to westerly. Again, there are no dust aerosols north of $20-25^{\circ} \mathrm{N}$ (Fig. 4, right).

\subsection{The role of the Intertropical Convergence Zone (ITCZ)}

The southern border of the SAL is closely connected all year round to the position of the ITCZ (Marticorena et al., 2011; Ben-Ami et al., 2012). Based on climatological data above the Atlantic, the ITCZ stays north of the Equator almost the entire year, and its position is about $3^{\circ} \mathrm{N}$ during winter and spring (it may even be southern), $10^{\circ} \mathrm{N}$ during summer and $8^{\circ} \mathrm{N}$ during autumn (Waliser and Gautier, 1993; $\mathrm{Hu}$ et al., 2007; Zagar et al., 2011). The same studies found the ITCZ position over South America to be around $10^{\circ} \mathrm{S}$ during winter (although large variations make it difficult to localize it precisely) and $3^{\circ} \mathrm{S}$ during spring. The approximate ITCZ position can be seen at $900 \mathrm{hPa}$ in Figs. 8 and 9, where the meridional wind is zero (Zagar et al., 2011, used the meridional wind averaged over 10 pressure levels of ERA-Interim data below $900 \mathrm{hPa}$ ). For the $5 \mathrm{yr}$ period examined here, during winter the ITCZ seems to be slightly north of the Equator $\left(5^{\circ} \mathrm{N}\right.$ close to Africa and $2^{\circ} \mathrm{N}$ close to South America) above the Atlantic, moving down to at least $10^{\circ} \mathrm{S}$ over South America. During spring, it seems to be over the Equator both above the Atlantic and South America, while during summer and fall it is at 10 and $8^{\circ} \mathrm{N}$ over the Atlantic, respectively. From the results of the previous section and the approximate position of the ITCZ, it can be observed that above the western Atlantic or South America, the SAL is either bounded by the ITCZ in the south (spring, summer and fall) or it never reaches the ITCZ (winter) (bottom plot of Figs. 8 and 9). However, over the eastern Atlantic the restriction of the SAL in the south by ITCZ can be clearly seen only during spring, while during winter and summer both CALIPSO and MODIS indicate the existence of dust aerosols, even south of ITCZ. The possibility of an artifact during winter by the inclusion of the polluted dust class (and thus biomass burning aerosols) in the analysis has been excluded in Sect. 3.1. During summer and fall, it can be noticed that the number of dust layers from CALIPSO is reduced south of the ITCZ (located at 10 and $8^{\circ} \mathrm{N}$, respectively) in comparison to northern latitudes (Fig. 2), while also only a part of SAL is found south of $10^{\circ} \mathrm{N}$ at about $3 \mathrm{~km}$ during summer (Fig. 4, left). To summarize, ITCZ does not appear as a rigorous southern boundary of SAL near Africa, meaning that it rather prevents a large number of dust layers from running through it than totally excluding the presence of SAL inside it. Possible reasons for the fact that SAL penetrates into ITCZ are manifold. It can be due to the influence of eddies related to African easterly waves, the different definition of ITCZ over the Atlantic and western Africa and consequently the improper use of the tropical rain belt from remote sensing studies to denote the ITCZ over western Africa (Nicholson, 2009) or the displacement of ITCZ during time (e.g., Doherty et al., 2012). Especially during winter, the weaker intensity of ITCZ over the east Atlantic may play a role (Waliser and Gautier, 1993, see their Fig. 1).

\subsection{African Easterly Jet and SAL}

An important feature that can be noticed in Figs. 8 and 9 at $700 \mathrm{hPa}$ (middle) is the collocation of SAL AOD maximum with a local maximum of the wind speed over the coast of western Africa for all seasons. This wind maximum, actually the African Easterly Jet (AEJ) (e.g., Wu et al., 2009; Lafore et al., 2011), is climatologically located at about $2^{\circ} \mathrm{N}$ and vertically $700 \mathrm{hPa}$ in winter and at $14^{\circ} \mathrm{N}$ and vertically $600 \mathrm{hPa}$ in summer (Afiesimama, 2007), a few degrees southward than seen in Figs. 8 and 9. The coincidence between AEJ and SAL in the vertical mostly happens at the upper levels of the SAL, as the AEJ is placed above $2 \mathrm{~km}$ in winter, rising to above $3 \mathrm{~km}$ in summer. Thus, the transport of dust aerosols in the upper levels of the SAL is realized within the AEJ close to Africa, which promotes the differential advection between the upper and lower parts of SAL. Karyampudi et al. (1999) mentioned that the SAL is transported westward by the AEJ (in their study referred to as the middle-level easterly jet), located near the southern edge of the SAL. However, firstly the AEJ is found mostly near western Africa, except for summer, in contrast to the SAL that reaches the Americas, and secondly, SAL presents higher extension than AEJ both spatially and vertically. These indicate that SAL is not transported by AEJ, but only a part of SAL interacts with AEJ. On the other hand, Tompkins et al. (2005) showed that a better description of aerosols especially over the Sahara in the ECMWF model significantly improved the forecast of AEJ structure and strength, via the direct radiative forcing. In addition, the AEJ is accelerated by approximately $4 \mathrm{~m} \mathrm{~s}^{-1}$ and is moved northward by $4-5^{\circ}$ during dust outbreaks compared to low-dust conditions (Wilcox et al., 2010). Thus, the existence of a strong interconnection between SAL and AEJ should be further studied. A first step to this end has been realized during the AMMA campaign, where the impact of SAL on African Easterly Waves (which develop though barotropic and baroclinic energy conversions as they move along the AEJ) has been examined (Zipser et al., 2009; Ismail et al., 2010; Lafore et al., 2011). 


\section{Summary and conclusions}

In this study, the vertical distribution of the Saharan Air Layer (SAL) is presented based on the detection of dust aerosols from CALIPSO above the Atlantic. Five-year CALIPSO observations of desert dust and polluted dust layers are used to depict the seasonal vertical distribution of SAL with $1^{\circ}$ horizontal resolution. These results offer a better description of the SAL, not accessible up to now, at least vertically. The desert dust and polluted dust classes have been merged in order to take into account the mixing of desert dust with other aerosol types (pollution, biomass burning, maritime), the aging of desert dust during its long-range transport to the Americas and the possible misclassification of desert dust as polluted dust by the CALIPSO algorithms. The possible overlap/overwrite of the layers has also been taken into account and corrected. The dust occurrence frequency (DOF) has been used in order to avoid the assumption about the lidar ratio, while the MODIS aerosol optical depth at $550 \mathrm{~nm}$ is also used as an additional and independent parameter to validate the spatial distribution of the SAL. The quality of our results is conditioned by the good quality of CALIOP's signal and the sound performance of CALIPSO algorithms in detecting the boundaries of aerosol or cloud layers, discriminating aerosols from clouds and recognizing dust aerosols from other classes due to depolarization ratio. It must be noted that the majority of previous studies (e.g., Karyampudi et al., 1999; Dunion and Velden, 2004; Zhu et al., 2007; Zipser et al., 2009; Braun, 2010; Nalli et al., 2011; Davidi et al., 2012) examined the SAL characteristics mainly during late spring to early fall, when the dust load is more significant and the hurricane and tropical cyclone activity peaks. Here, we show that SAL exists all year round at least in relation to dust aerosols examined.

The CALIPSO data indicate that SAL presents a clear seasonal cycle and appears northern in latitude and higher in altitude during summer than during winter. This seasonality is in agreement with the results of Prospero et al. (2012) (see their Fig. 3). Its spatial extent at $20^{\circ} \mathrm{W}$ is found between $5^{\circ} \mathrm{S}$ and $15^{\circ} \mathrm{N}$ in winter and between 5 and $30^{\circ} \mathrm{N}$ in summer. Towards the east Caribbean Sea $\left(50^{\circ} \mathrm{W}\right), \mathrm{SAL}$ is observed in the interval $5^{\circ} \mathrm{S}-10^{\circ} \mathrm{N}$ in winter and at $10-25^{\circ} \mathrm{N}$ in summer, although it can reach the longitudes of $60^{\circ} \mathrm{W}$ during winter and $90^{\circ} \mathrm{W}$ in summer. During the transitory seasons of spring and fall, SAL is found between the position of winter and summer not only spatially, but also vertically. In winter, SAL occurs in the altitude range $0-3 \mathrm{~km}$ at $20^{\circ} \mathrm{W}$, reducing to $0-2 \mathrm{~km}$ over eastern South America $\left(50^{\circ} \mathrm{W}\right)$. During summer, SAL is found more elevated close to Africa $\left(20^{\circ} \mathrm{W}\right)$ at 1 to $5 \mathrm{~km}$ going down to $0-2 \mathrm{~km}$ in the Gulf of Mexico (80$90^{\circ} \mathrm{W}$ ). These results are generally in good agreement with previous studies, although the majority of these studies only deal with a limited number of cases, mainly in summer and close to western Africa.
The vertical distribution of SAL does not generally show a multilayer structure, but rather only one dust layer, which justifies the use of notions as mean altitude and mean geometrical thickness. During winter the mean altitude decreases with westward transport by $13 \mathrm{~m} \mathrm{deg}^{-1}$ and the mean geometrical thickness by $25 \mathrm{~m} \mathrm{deg}^{-1}$, while in summer the mean altitude decreases westward of $30^{\circ} \mathrm{W}$ by $28 \mathrm{~m} \mathrm{deg}^{-1}$ and the mean geometrical thickness by $9 \mathrm{~m} \mathrm{deg}^{-1}$. Thus, the decrease tendency is inverted between the altitude and geometrical thickness during the two opposite seasons, while the two transition seasons present similar characteristics. The abovementioned results with the wind speed from ECMWF permit the estimation of the effective dry deposition velocity of dust particles. This is $0.07 \mathrm{~cm} \mathrm{~s}^{-1}$ in winter, $0.14 \mathrm{~cm} \mathrm{~s}^{-1}$ in spring, $0.2 \mathrm{~cm} \mathrm{~s}^{-1}$ in summer and $0.11 \mathrm{~cm} \mathrm{~s}^{-1}$ in fall.

We have shown that the wind field not only determines the transport of SAL but also modulates its shape. During winter the trade winds transport SAL towards South America, while in spring and summer they prevent its efficient mixing inside the marine boundary layer and erode the lower part of SAL by bringing dust-free maritime air masses from the North Atlantic westward of about $50^{\circ} \mathrm{W}$, which is in agreement with previous studies. The trade winds from the Southern Hemisphere erode the low levels of the southern part of the SAL less efficiently, but its structure can be still clearly observed, especially during summer. On the other hand, the North Atlantic westerlies, with their southern border occurring between 15 and $30^{\circ} \mathrm{N}$ (depending on the season, the longitude and the altitude), prevent the SAL from developing further northward. In addition, their southward shift with altitude gives SAL its characteristic oval shape in its northern part, as shown here, to the best of our knowledge, for the first time. Concerning the southern part of the SAL, the ITCZ is the central feature that determines its southern border. However, above the eastern tropical Atlantic some dust layers can be seen in or south of the ITCZ, indicating that ITCZ does not inhibit the penetration of dust aerosols but rather reduces it significantly. It was also observed that the AEJ collocates with the maximum dust load, a fact that may induce the development of differential advection within the SAL, especially during summer.

These results should be helpful to examine how well models reproduce the SAL vertical distribution on a seasonal scale or could be used as input data to models describing the vertical distribution of dust aerosols above the Atlantic (e.g., Koffi et al., 2012). Also, they can be used as a priori information (vertical distribution of dust aerosols) in satellite algorithms, which analyze data from instruments either in the UV spectrum (like TOMS or OMI) or in the IR spectrum (like AIRS or IASI) in order to improve the quality of their geophysical retrievals, as these instruments are sensitive to the vertical distribution. Further, as there are growing efforts to obtain the height of aerosols plumes from passive satellite instruments (Kahn et al., 2007; Joseph et al., 2008; 
Kokhanovsky and Rozanov, 2010; Peyridieu et al., 2010, 2013), these results comprise a validation data set.

Finally, there is a need for systematic measurements of the SAL vertical distribution not only at both sides of the Atlantic but also over it in order to further validate the CALIPSO results presented here. A step forward has been achieved with the AEROSE shipborne campaigns (Nalli et al., 2005, 2011), which observed the SAL vertical distribution using mainly radiosondes and sun photometer data at the ship level. However, because dry air outbreaks from Africa into the tropical Atlantic are not always related to African dust outbreaks (Zhang and Pennington, 2004), and due to the connection of SAL with wind (and AEJ), future campaigns or long-term measurement sites should combine vertical measurements of dust aerosols, temperature, humidity and wind reaching at least up to $7 \mathrm{~km}$ in order not to miss the upper parts of SAL. The combination of all these parameters is important if we want to understand in depth the impacts of SAL on the environment over the Atlantic and the adjacent continents.

\section{Appendix A}

Figures A1-A4 are presented here as additional material in order to give a more complete picture of the SAL by exploiting the main advantage of CALIOP, which is its fine vertical resolution. Also, they provide the spatial extension of the SAL as seen from CALIPSO. For every season, the DOF is depicted at six vertical levels, which correspond to pressure levels of ERA-Interim data at $900(\sim 1 \mathrm{~km}$, bottom left), 800 ( $\sim 2 \mathrm{~km}$, middle left), $700(\sim 3 \mathrm{~km}$, top left), 650 ( $\sim 3.5 \mathrm{~km}$, bottom right), $600(\sim 4.2 \mathrm{~km}$, middle right) and $550 \mathrm{hPa}(\sim 4.8 \mathrm{~km}$, top right). At every level the wind direction from ECMWF at this pressure is denoted by the black vectors, and the wind speed is given by the magenta isolines with a step of $3 \mathrm{~ms}^{-1}$.

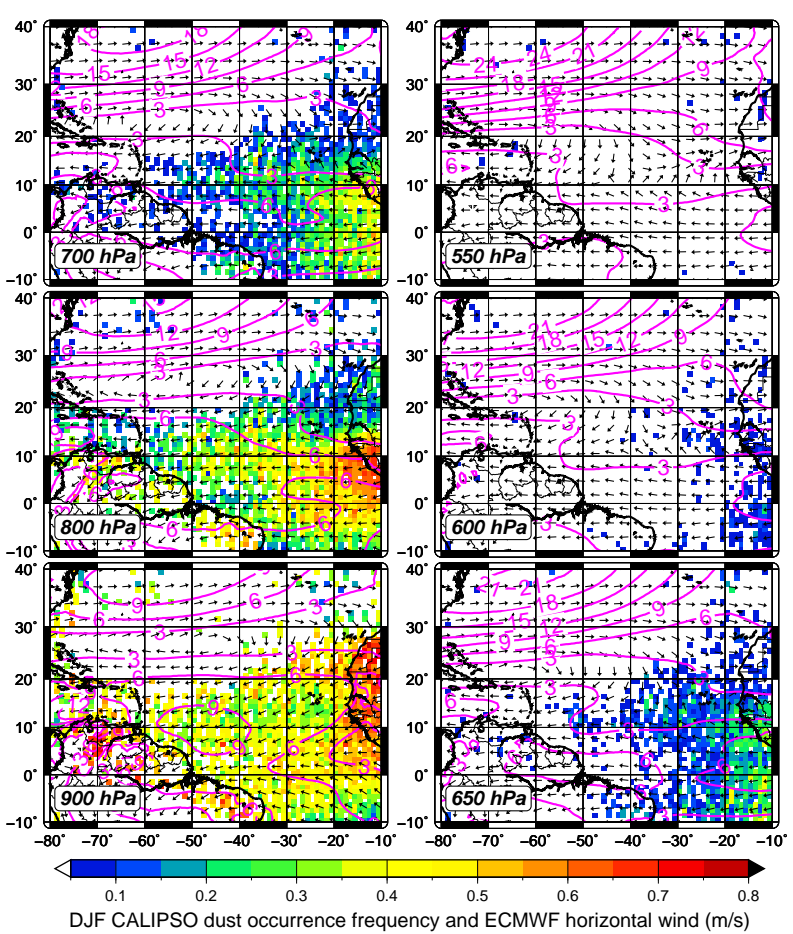

Fig. A1. Winter (DJF) CALIPSO dust occurrence frequency (colorscale) at six pressure levels with ECMWF horizontal wind direction (black vectors) and speed (magenta isolines). See text for details.

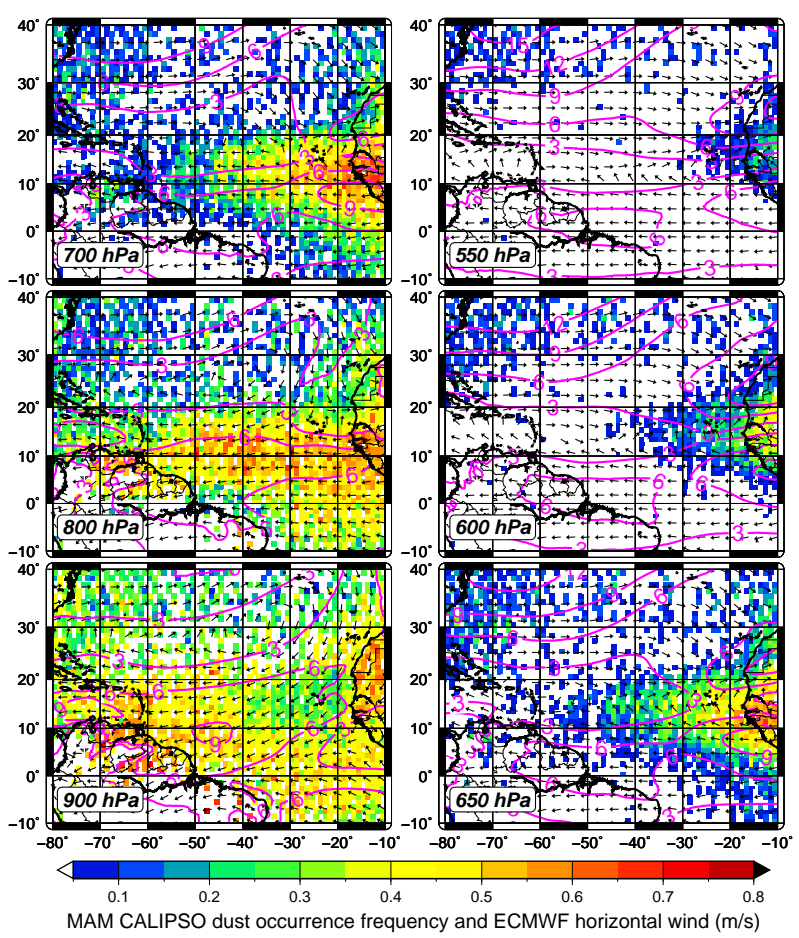

Fig. A2. Same as Fig. A1 but for spring (MAM). 


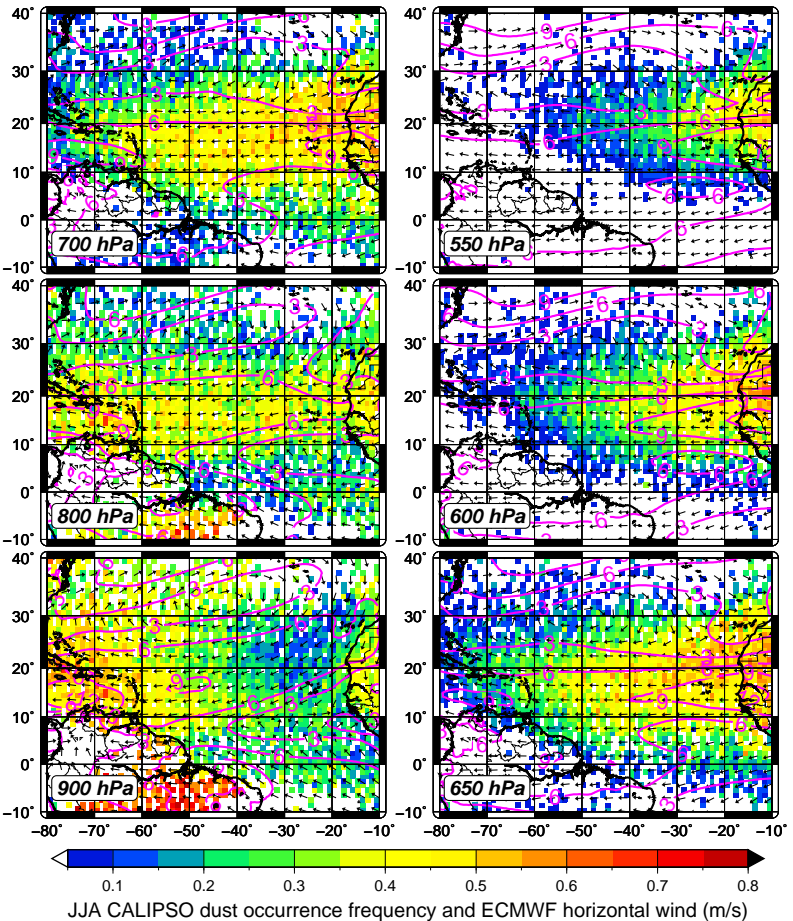

Fig. A3. Same as Fig. A1 but for summer (JJA).

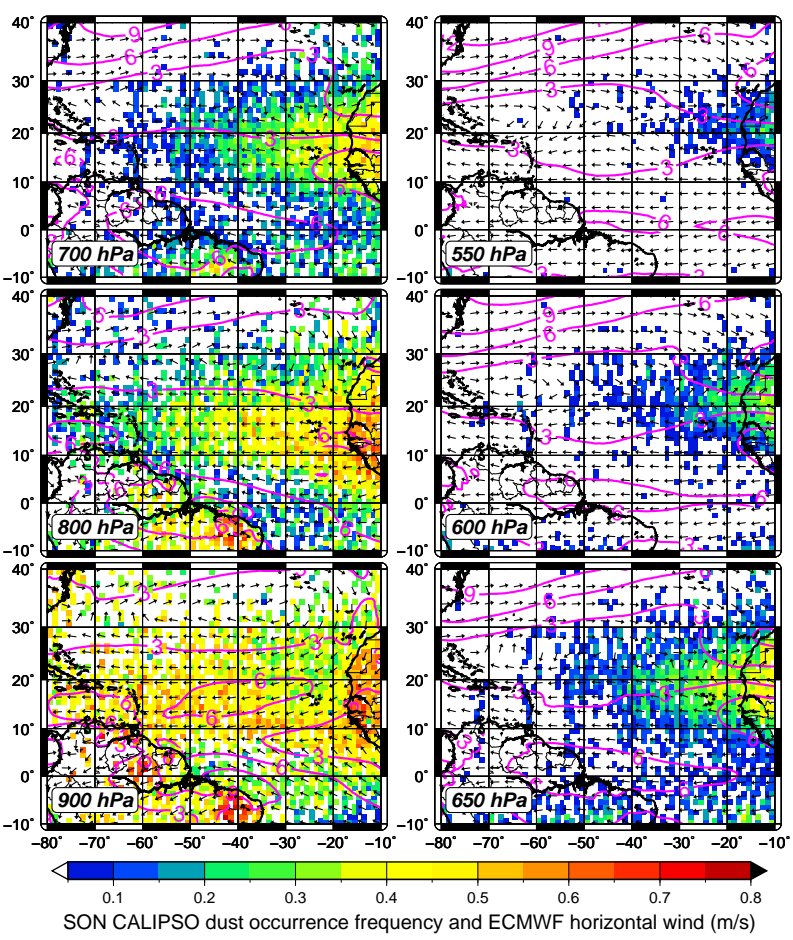

Fig. A4. Same as Fig. A1 but for fall (SON).
Acknowledgements. CALIPSO NASA and CNES scientific teams and the MODIS scientific team are gratefully acknowledged for providing high-quality satellite data. We thank NASA/LaRC and ICARE Data and Services Center (http://www.icare.univ-lille1.fr) for providing us with CALIPSO data. MODIS data were obtained through NASA's Giovanni, developed and maintained by the NASA GES DISC. S. Peyridieu is acknowledged for assistance regarding acquisition of CALIPSO data. We thank the reviewers for helping us to improve the quality of our paper and Yaswant Pradhan for correcting grammatical mistakes. This work has been supported in part by the European Community under the contract FP7/MACC II project, grant agreement no. 283576.

Edited by: O. Dubovik

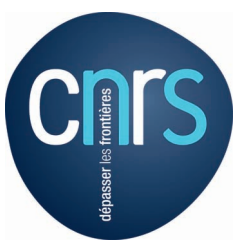

The publication of this article is financed by CNRS-INSU.

\section{References}

Adams, A. M., Prospero, J. M., and Zhang, C.: CALIPSOderived three-dimensional structure of aerosol over the Atlantic Basin and adjacent continents, J. Climate, 25, 6862-6879, doi:10.1175/JCLI-D-11-00672.1, 2012.

Afiesimama, E. A.: Annual cycle of the mid-tropospheric easterly jet over West Africa, Theor. Appl. Climatol., 90, 103-111, doi:10.1007/s00704-006-0284-y, 2007.

Alpert, P., Kaufman, Y. J., Shay-El, Y., Tanre, D., da Silva, A., Schubert, S., and Joseph, J.: Quantification of dust-forced heating of the lower troposphere, Nature, 395, 367-370, 1998.

Andreae, M. O. and Crutzen, P. J.: Atmospheric aerosols: biogeochemical sources and role in atmospheric chemistry, Science, 276, 1052-1058, 1997.

Ansmann, A., Baars, H., Tesche, M., Muller, D., Althausen, D., Engelmann, R., Pauliquevis, T., and Artaxo, P.: Dust and smoke transport from Africa to South America: Lidar profiling over Cape Verde and the Amazon rainforest, Geophys. Res. Lett., 36, L11802, doi:10.1029/2009GL037923, 2009.

Baars, H., Ansmann, A., Althausen, D., Engelmann, R., Artaxo, P., Pauliquevis, T., and Souza, R.: Further evidence for significant smoke transport from Africa to Amazonia, Geophys. Res. Lett., 38, L20802, doi:10.1029/2011GL049200, 2011.

Balis, D. S., Amiridis, V., Nickovic, S., Papayannis, A., and Zerefos, C.: Optical properties of Saharan dust layers as detected by a Raman lidar at Thessaloniki, Greece, Geophys. Res. Lett., 31, L13104, doi:10.1029/2004GL019881, 2004.

Ben-Ami, Y., Koren, I., and Altaratz, O.: Patterns of North African dust transport over the Atlantic: winter vs. summer, based on CALIPSO first year data, Atmos. Chem. Phys., 9, 7867-7875, doi:10.5194/acp-9-7867-2009, 2009.

Ben-Ami, Y., Koren, I., Rudich, Y., Artaxo, P., Martin, S. T., and Andreae, M. O.: Transport of North African dust from the Bodélé depression to the Amazon Basin: a case study, Atmos. Chem. Phys., 10, 7533-7544, doi:10.5194/acp-10-7533-2010, 2010. 
Ben-Ami, Y., Koren, I., Altaratz, O., Kostinski, A., and Lehahn, Y.: Discernible rhythm in the spatio/temporal distributions of transatlantic dust, Atmos. Chem. Phys., 12, 2253-2262, doi:10.5194/acp-12-2253-2012, 2012.

Braun, S. A.: Reevaluating the role of the Saharan Air Layer in Atlantic tropical cyclogenesis and evolution, Mon. Weather Rev., 138, 2007-2037, doi:10.1175/2009MWR3135.1, 2010.

Breon, F.-M., Vermeulen, A., and Descloitres, J.: An evaluation of satellite aerosol products against sunphotometer measurements, Remote Sens. Environ., 115, 3102-3111, doi:10.1016/j.rse.2011.06.017, 2011.

Bristow, C. S., Hudson-Edwards, K. A., and Chappell, A.: Fertilizing the Amazon and equatorial Atlantic with West African dust, Geophys. Res. Lett., 37, L14807, doi:10.1029/2010GL043486, 2010.

Cattrall, C., Reagan, J., Thome, K., and Dubovik, O.: Variability of aerosol and spectral lidar and backscatter and extinction ratios of key aerosol types derived from selected Aerosol Robotic Network locations, J. Geophys. Res., 110, D10S11, doi:10.1029/2004JD005124, 2005.

Chen, S.-H., Wang, S.-H., and Waylonis, M.: Modification of Saharan air layer and environmental shear over the eastern Atlantic Ocean by dust-radiation effects, J. Geophys. Res., 115, D21202, doi:10.1029/2010JD014158, 2010.

Chiapello, I., Bergametti, G., Gomes, L., Chatenet, B., Dulac, F., Pimenta, J., and Santos Suares, E.: An additional low layer transport of Sahelian and Saharan dust over the North-Eastern Tropical Atlantic, Geophys. Res. Lett., 22, 31913194, doi:10.1029/95GL03313, 1995.

Christopher, S. A. and Jones, T. A.: Satellite and surface-based remote sensing of Saharan dust aerosols, Remote Sens. Environ., 114, 1002-1007, doi:10.1016/j.rse.2009.12.007, 2010.

Colarco, P. R., Toon, O. B., Reid, J. S., Livingston, J. M., Russell, P. B., Redemann, J., Schmid, B., Maring, H. B., Savoie, D., Welton, E. J., Campbell, J. R., Holben, B. N., and Levy, R.: Saharan dust transport to the Caribbean during PRIDE: 2. Transport, vertical profiles, and deposition in simulations of in situ and remote sensing observations, J. Geophys. Res., 108, 8590, doi:10.1029/2002JD002659, 2003.

Davidi, A., Kostinski, A. B., Koren, I., and Lehahn, Y.: Observational bounds on atmospheric heating by aerosol absorption: radiative signature of transatlantic dust, Geophys. Res. Lett., 39, L04803, doi:10.1029/2011GL050358, 2012.

de Reus, M., Fischer, H., Sander, R., Gros, V., Kormann, R., Salisbury, G., Van Dingenen, R., Williams, J., Zöllner, M., and Lelieveld, J.: Observations and model calculations of trace gas scavenging in a dense Saharan dust plume during MINATROC, Atmos. Chem. Phys., 5, 1787-1803, doi:10.5194/acp-5-17872005, 2005.

Dee, D. P., Uppala, S. M., Simmons, A. J., Berrisford, P., Poli, P., Kobayashi, S., Andrae, U., Balmaseda, M. A., Balsamo, G., Bauer, P., Bechtold, P., Beljaars, A. C. M., van de Berg, L., Bidlot, J., Bormann, N., Delsol, C., Dragani, R., Fuentes, M., Geer, A. J., Haimberger, L., Healy, S. B., Hersbach, H., Holm, E. V., Isaksen, L., Kallberg, P., Kohler, M., Matricardi, M., McNally, A. P., Monge-Sanz, B. M., Morcrette, J.-J., Park, B.K., Peubey, C., de Rosnay, P., Tavolato, C., Thepaut, J.-N., and Vitart, F.: The ERA-Interim reanalysis: configuration and perfor- mance of the data assimilation system, Q. J. Roy. Meteorol. Soc., 137, 553-597, doi:10.1002/qj.828, 2011.

DeMott, P. J., Sassen, K., Poellot, M. R., Baumgardner, D., Rogers, D. C., Brooks, S. D., Prenni, A. J., and Kreidenweis, S. M.: African dust aerosols as atmospheric ice nuclei, Geophys. Res. Lett., 30, 1732, doi:10.1029/2003GL017410, 2003.

Doherty, O. M., Riemer, N., and Hameed, S.: Saharan mineral dust transport into the Caribbean: observed atmospheric controls and trends, J. Geophys. Res., 113, doi:10.1029/2007JD009171, 2008.

Doherty, O. M., Riemer, N., and Hameed, S.: Control of Saharan mineral dust transport to Barbados in winter by the Intertropical Convergence Zone over West Africa, J. Geophys. Res., 117, D19117, doi:10.1029/2012JD017767, 2012.

Dulac, F., Tanre, D., Bergametti, G., Buat-Menard, P., Desbois, M., and Sutton, D.: Assessment of the African airborne dust mass over the western Mediterranean Sea using Meteosat data, J. Geophys. Res., 97, 2489-2506, doi:10.1029/91JD02427, 1992.

Dunion, J. P. and Marron, C. S.: A reexamination of the Jordan mean tropical sounding based on awareness of the Saharan Air Layer: results from 2002, J. Climate, 21, 5242-5253, doi:10.1175/2008JCLI1868.1, 2008.

Dunion, J. P. and Velden, C. S.: The impact of the Saharan Air Layer on Atlantic tropical cyclone activity, B. Am. Meteorol. Soc., 85, 353-365, doi:10.1175/BAMS-85-3-353, 2004.

Evan, A. T., Dunion, J., Foley, J. A., Heidinger, A. K., and Velden, C. S.: New evidence for a relationship between Atlantic tropical cyclone activity and African dust outbreaks, Geophys. Res. Lett., 33, L19813, doi:10.1029/2006GL026408, 2006.

Evan, A. T., Vimont, D. J., Heidinger, A. K., Kossin, J. P., and Bennartz, R.: The role of aerosols in the evolution of tropical North Atlantic Ocean temperature anomalies, Science, 324, 778-781, doi:10.1126/science.1167404, 2009.

Evan, A. T., Foltz, G. R., Zhang, D., and Vimont, D. J.: Influence of African dust on ocean-atmosphere variability in the tropical Atlantic, Nat. Geosci., 4, 762-765, doi:10.1038/NGEO1276, 2011.

Foret, G., Bergametti, G., Dulac, F., and Menut, L.: An optimized particle size bin scheme for modeling mineral dust aerosol, J. Geophys. Res., 111, D17310, doi:10.1029/2005JD006797, 2006.

Formenti, P., Andreae, M. O., Lange, L., Roberts, G., Cafmeyer, J., Rajta, I., Maenhaut, W., Holben, B. N., Artaxo, P., and Lelieveld, J.: Saharan dust in Brazil and Suriname during the Large-Scale Biosphere-Atmosphere Experiment in Amazonia (LBA)-Cooperative LBA Regional Experiment (CLAIRE) in March 1998, J. Geophys. Res., 106, 14919-14934, doi:10.1029/2000JD900827, 2001.

Formenti, P., Rajot, J. L., Desboeufs, K., Caquineau, S., Chevaillier, S., Nava, S., Gaudichet, A., Journet, E., Triquet, S., Alfaro, S., Chiari, M., Haywood, J., Coe, H., and Highwood, E.: Regional variability of the composition of mineral dust from western Africa: results from the AMMA SOP0/DABEX and DODO field campaigns, J. Geophys. Res., 113, D00C13, doi:10.1029/2008JD009903, 2008.

Formenti, P., Schütz, L., Balkanski, Y., Desboeufs, K., Ebert, M., Kandler, K., Petzold, A., Scheuvens, D., Weinbruch, S., and Zhang, D.: Recent progress in understanding physical and chemical properties of African and Asian mineral dust, Atmos. Chem. Phys., 11, 8231-8256, doi:10.5194/acp-11-8231-2011, 2011. 
Generoso, S., Bey, I., Labonne, M., and Breon, F.-M.: Aerosol vertical distribution in dust outflow over the Atlantic: comparisons between GEOS-Chem and Cloud-Aerosol Lidar and Infrared Pathfinder Satellite Observation (CALIPSO), J. Geophys. Res., 113, D24209, doi:10.1029/2008JD010154, 2008.

Giglio, L., Csiszar, I., and Justice, C. O.: Global distribution and seasonality of active fires as observed with the Terra and Aqua Moderate Resolution Imaging Spectroradiometer (MODIS) sensors, J. Geophys. Res., 111, G02016, doi:10.1029/2005JG000142, 2006.

Ginoux, P. and Torres, O.: Empirical TOMS index for dust aerosol: applications to model validation and source characterization, J. Geophys. Res., 108, 4534, doi:10.1029/2003JD003470, 2003.

Gross, S., Tesche, M., Freudenthaler, V., Toledano, C., Wiegner, M., Ansmann, A., Althausen, D., and Seefeldner, M.: Characterization of Saharan dust, marine aerosols and mixtures of biomassburning aerosols and dust by means of multi-wavelength depolarization and Raman lidar measurements during SAMUM 2, Tellus, 63, 706-724, doi:10.1111/j.1600-0889.2011.00556.x, 2011.

Haywood, J. M., Pelon, J., Formenti, P., Bharmal, N., Brooks, M., Capes, G., Chazette, P., Chou, C., Christopher, S., Coe, H., Cuesta, J., Derimian, Y., Desboeufs, K., Greed, G., Harrison, M., Heese, B., Highwood, E. J., Johnson, B., Mallet, M., Marticorena, B., Marsham, J., Milton, S., Myhre, G., Osborne, S. R., Parker, D. J., Rajot, J.-L., Schulz, M., Slingo, A., Tanre, D., and Tulet, P.: Overview of the Dust and Biomass-burning Experiment and African Monsoon Multidisciplinary Analysis Special Observing Period-0, J. Geophys. Res., 113, D00C17, doi:10.1029/2008JD010077, 2008.

Hu, Y., Li, D., and Liu, J.: Abrupt seasonal variation of the ITCZ and the Hadley circulation, Geophys. Res. Lett., 34, L18814, doi:10.1029/2007GL030950, 2007.

Huang, J., Zhang, C., and Prospero, J. M.: African dust outbreaks: a satellite perspective of temporal and spatial variability over the tropical Atlantic Ocean, J. Geophys. Res., 115, D05202, doi:10.1029/2009JD012516, 2010.

Immler, F. and Schrems, O.: Vertical profiles, optical and microphysical properties of Saharan dust layers determined by a ship-borne lidar, Atmos. Chem. Phys., 3, 1353-1364, doi:10.5194/acp-3-1353-2003, 2003.

Ismail, S., Ferrare, R. A., Browell, E. V., Kooi, S. A., Dunion, J. P., Heymsfield, G., Notari, A., Butler, C. F., Burton, S., Fenn, M., Krishnamurti, T. N., Biswas, M. K., Chen, G., and Anderson, B.: LASE measurements of water vapor, aerosol, and cloud distributions in Saharan air layers and tropical disturbances, J. Atmos. Sci., 67, 1026-1047, doi:10.1175/2009JAS3136.1, 2010.

Iwasaka, Y., Shibata, T., Nagatani, T., Shi, G.-Y., Kim, Y. S., Matsuki, A., Trochkine, D., Zhang, D., Yamada, M., Nagatani, M., Nakata, H., Shen, Z., Li, G., Chen, B., and Kawahira, K.: Large depolarization ratio of free tropospheric aerosols over the Taklamakan Desert revealed by lidar measurements: possible diffusion and transport of dust particles, J. Geophys. Res., 108, 8652, doi:10.1029/2002JD003267, 2003.

Jenkins, G. S., Pratt, A. S., and Heymsfield, A.: Possible linkages between Saharan dust and tropical cyclone rain band invigoration in the eastern Atlantic during NAMMA-06, Geophys. Res. Lett., 35, L08815, doi:10.1029/2008GL034072, 2008.

Jenkins, G. S., Robjhon, M. L., Smith, J. W., Clark, J., and Mendes, L.: The influence of the SAL and lightning on tropo- spheric ozone variability over the Northern Tropical Atlantic: results from Cape Verde during 2010, Geophys. Res. Lett., 39, L20810, doi:10.1029/2012GL053532, 2012.

Jickells, T. D., An, Z. S., Andersen, K. K., Baker, A. R., Bergametti, G., Brooks, N., Cao, J. J., Boyd, P. W., Duce, R. A., Hunter, K. A., Kawahata, H., Kubilay, N., laRoche, J., Liss, P. S., Mahowald, N., Prospero, J. M., Ridgwell, A. J., Tegen, I., and Torres, R.: Global iron connections between desert dust, ocean biogeochemistry, and climate, Science, 308, 67-71, doi:10.1126/science.1105959, 2005.

Johnson, B. T., Heese, B., McFarlane, S. A., Chazette, P., Jones, A., and Bellouin, N.: Vertical distribution and radiative effects of mineral dust and biomass burning aerosol over West Africa during DABEX, J. Geophys. Res., 113, D00C12, doi:10.1029/2008JD009848, 2008.

Joseph, J. H., Yaron, O., Yaroslavich, E., Israelevich, P., Koren, I., Yair, Y., Devir, A., and Kischa, P.: Determination of most probable height of desert dust aerosol layer from space, J. Geophys. Res., 113, D20S93, doi:10.1029/2007JD009646, 2008.

Kahn, R. A., Li, W.-H., Moroney, C., Diner, D. J., Martonchik, J. V., and Fishbein, E.: Aerosol source plume physical characteristics from space-based multiangle imaging, J. Geophys. Res., 112, D11205, doi:10.1029/2006JD007647, 2007.

Kalashnikova, O. V. and Kahn, R. A.: Mineral dust plume evolution over the Atlantic from MISR and MODIS aerosol retrievals, J. Geophys. Res., 113, D24204, doi:10.1029/2008JD010083, 2008.

Karyampudi, V. M., Palm, S. P., Reagen, J. A., Fang, H., Grant, W. B., Hoff, R. M., Moulin, C., Pierce, H. F., Torres, O., Browell, E. V., and Melfi, S. H.: Validation of the Saharan dust plume conceptual model using lidar, Meteosat, and ECMWF data, B. Am. Meteorol. Soc., 80, 1045-1075, doi:10.1175/15200477(1999)080<1045:VOTSDP>2.0.CO;2, 1999.

Kaufman, Y. J., Koren, I., Remer, L. A., Tanre, D., Ginoux, P., and Fan, S.: Dust transport and deposition observed from the TerraModerate Resolution Imaging Spectroradiometer (MODIS) spacecraft over the Atlantic Ocean, J. Geophys. Res., 110, D10S12, doi:10.1029/2003JD004436, 2005.

Kittaka, C., Winker, D. M., Vaughan, M. A., Omar, A., and Remer, L. A.: Intercomparison of column aerosol optical depths from CALIPSO and MODIS-Aqua, Atmos. Meas. Tech., 4, 131-141, doi:10.5194/amt-4-131-2011, 2011.

Knippertz, P., Tesche, M., Heinold, B., Kandler, K., Toledano, C., and Esselborn, M.: Dust mobilization and aerosol transport from West Africa to Cape Verde - a meteorological overview of SAMUM-2, Tellus, 63, 430-447, doi:10.1111/j.16000889.2011.00544.x, 2011.

Koffi, B., Schulz, M., Breon, F.-M., Griesfeller, J., Winker, D., Balkanski, Y., Bauer, S., Berntsen, T., Chin, M., Collins, W. D., Dentener, F., Diehl, T., Easter, R., Ghan, S., Ginoux, P., Gong, S., Horowitz, L. W., Iversen, T., Kirkevag, A., Koch, D., Krol, M., Myhre, G., Stier, P., and Takemura, T.: Application of the CALIOP layer product to evaluate the vertical distribution of aerosols estimated by global models: AeroCom phase I results, J. Geophys. Res., 117, D10201, doi:10.1029/2011JD016858, 2012.

Kokhanovsky, A. A. and Rozanov, V. V.: The determination of dust cloud altitudes from a satellite using hyperspectral measurements in the gaseous absorption band, Int. J. Remote Sens., 31, 2729 2744, doi:10.1080/01431160903085644, 2010. 
Koren, I., Kaufman, Y. J., Washington, R., Todd, M. C., Rudich, Y., Martins, J. V., and Rosenfeld, D.: The Bodélé depression: a single spot in the Sahara that provides most of the mineral dust to the Amazon forest, Environ. Res. Lett., 1, 014005, doi:10.1088/1748-9326/1/1/014005, 2006.

Lafore, J.-P., Flamant, C., Guichard, F., Parker, D. J., Bouniol, D., Fink, A. H., Giraud, V., Gosset, M., Hall, N., Holler, H., Jones, S. C., Protat, A., Roca, R., Roux, F., Said, F., and Thorncroft, C.: Progress in understanding of weather systems in West Africa, Atmos. Sci. Lett., 12, 7-12, doi:10.1002/asl.335, 2011.

Lau, K. M. and Kim, K. M.: Cooling of the Atlantic by Saharan dust, Geophys. Res. Lett., 34, L23811, doi:10.1029/2007GL031538, 2007.

Léon, J.-F., Derimian, Y., Chiapello, I., Tanré, D., Podvin, T., Chatenet, B., Diallo, A., and Deroo, C.: Aerosol vertical distribution and optical properties over M'Bour $\left(16.96^{\circ} \mathrm{W} ; 14.39^{\circ} \mathrm{N}\right)$, Senegal from 2006 to 2008, Atmos. Chem. Phys., 9, 9249-9261, doi:10.5194/acp-9-9249-2009, 2009.

Liao, H. and Seinfeld, J. H.: Radiative forcing by mineral dust aerosols: sensitivity to key variables, J. Geophys. Res., 103, 31637-31645, doi:10.1029/1998JD200036, 1998.

Liu, D., Wang, Z., Liu, Z., Winker, D., and Trepte, C.: A height resolved global view of dust aerosols from the first year CALIPSO lidar measurements, J. Geophys. Res., 113, D16214, doi:10.1029/2007JD009776, 2008a.

Liu, Z., Omar, A., Vaughan, M., Hair, J., Kittaka, C., Hu, Y., Powell, K., Trepte, C., Winker, D., Hostetler, C., Ferrare, R., and Pierce, R.: CALIPSO lidar observations of the optical properties of Saharan dust: a case study of long-range transport, J. Geophys. Res., 113, D07207, doi:10.1029/2007JD008878, 2008b.

Liu, Z., Vaughan, M. A., Winker, D. M., Kittaka, C., Getzewich, B., Kuehn, R., Omar, A., Powell, K., Trepte, C., and Hostetler, C.: The CALIPSO lidar cloud and aerosol discrimination: version 2 algorithm and initial assessment of performance, J. Atmos. Ocean. Tech., 26, 1198-1213, doi:10.1175/2009JTECHA1229.1, 2009.

Liu, Z., Kuehn, R., Vaughan, M., Winker, D., Omar, A., Powell, K., Trepte, C., Hu, Y., and Hostetler, C.: The CALIPSO cloud and aerosol discrimination: version 3 algorithm and test results, in: 25th International Laser Radar Conference (ILRC), St. Petersburg, Russia, 5-9 July, 2010.

Maddy, E. S., DeSouza-Machado, S. G., Nalli, N. R., Barnet, C. D., Strow, L. L., Wolf, W. W., Xie, H., Gambacorta, A., King, T. S., Joseph, E., Morris, V., Hannon, S. E., and Schou, P.: On the effect of dust aerosols on AIRS and IASI operational level 2 products, Geophys. Res. Lett., 39, L10809, doi:10.1029/2012GL052070, 2012.

Maher, B. A., Prospero, J. M., Mackie, D., Gaiero, D., Hesse, P. P., and Balkanski, Y.: Global connections between aeolian dust, climate and ocean biogeochemistry at the present day and at the last glacial maximum, Earth-Sci. Rev., 99, 61-97, doi:10.1016/j.earscirev.2009.12.001, 2010.

Mahowald, N. M. and Kiehl, L. M.: Mineral aerosol and cloud interactions, Geophys. Res. Lett., 30, 1475, doi:10.1029/2002GL016762, 2003.

Maring, H., Savoie, D. L., Izaguirre, M. A., Custals, L., and Reid, J. S.: Mineral dust aerosol size distribution change during atmospheric transport, J. Geophys. Res., 108, 8592, doi:10.1029/2002JD002536, 2003.
Marticorena, B., Haywood, J., Coe, H., Formenti, P., Liousse, C., Mallet, M., and Pelon, J.: Tropospheric aerosols over West Africa: highlights from the AMMA international program, Atmos. Sci. Lett., 12, 19-23, doi:10.1002/asl.322, 2011.

Mattis, I., Ansmann, A., Muller, D., Wandinger, U., and Althausen, D.: Dual-wavelength Raman lidar observations of the extinction-to-backscatter ratio of Saharan dust, Geophys. Res. Lett., 29, 20-1-20-4 doi:10.1029/2002GL014721, 2002.

McConnell, C. L., Highwood, E. J., Coe, H., Formenti, P., Anderson, B., Osborne, S., Nava, S., Desboeufs, K., Chen, G., and Harrison, M. A. J.: Seasonal variations of the physical and optical characteristics of Saharan dust: results from the Dust Outflow and Deposition to the Ocean (DODO) experiment, J. Geophys. Res., 113, D14S05, doi:10.1029/2007JD009606, 2008.

Meloni, D., di Sarra, A., Di Iorio, T., and Fiocco, G.: Influence of the vertical profile of Saharan dust on the visible direct radiative forcing, J. Quant. Spectrosc. Ra., 93, 397-413, doi:10.1016/j.jqsrt.2004.08.035, 2005.

Mielonen, T., Arola, A., Komppula, M., Kukkonen, J., Koskinen, J., de Leeuw, G., and Lehtinen, K. E. J.: Comparison of CALIOP level 2 aerosol subtypes to aerosol types derived from AERONET inversion data, Geophys. Res. Lett., 36, L18804, doi:10.1029/2009GL039609, 2009.

Muller, D., Ansmann, A., Mattis, I., Tesche, M., Wandinger, U., Althausen, D., and Pisani, G.: Aerosol-type-dependent lidar ratios observed with Raman lidar, J. Geophys. Res., 112, D16202, doi:10.1029/2006JD008292, 2007.

Nalli, N. R., Clemente-Colon, P., Morris, V., Joseph, E., Szczodrak, M., Minnett, P. J., Shannahoff, J., Goldberg, M. D., Barnet, C., Wolf, W. W., Feltz, W. F., and Knuteson, R. O.: Profile observations of the Saharan air layer during AEROSE 2004, Geophys. Res. Lett., 32, L05815, doi:10.1029/2004GL022028, 2005.

Nalli, N. R., Joseph, E., Morris, V. R., Barnet, C. D., Wolf, W. W., Wolfe, D., Minnett, P. J., Szczodrak, M., Izaguirre, M. A., Lumpkin, R., Xie, H., Smirnov, A., King, T. S., and Wei, J.: Multiyear observations of the tropical Atlantic atmosphere: multidisciplinary applications of the NOAA aerosols and ocean science expeditions, B. Am. Meteorol. Soc., 92, 765-789, doi:10.1175/2011BAMS2997.1, 2011.

Nicholson, S. E.: A revised picture of the structure of the "monsoon" and land ITCZ over West Africa, Climate Dynamics, 32, 1155-1171, doi:10.1007/s00382-008-0514-3, 2009.

Noll, K. E. and Aluko, O.: Changes in large particle size distribution due to dry deposition processes, J. Aerosol Sci., 37, 1797-1808, doi:10.1016/j.jaerosci.2006.08.006, 2006.

Omar, A. H., Winker, D. M., Kittaka, C., Vaughan, M. A., Liu, Z., Hu, Y., Trepte, C. R., Rogers, R. R., Ferrare, R. A., Lee, K.-P., Kuehn, R. E., and Hostetler, C. A.: The CALIPSO automated aerosol classification and lidar ratio selection algorithm, J. Atmos. Ocean. Tech., 26, 1994-2014, doi:10.1175/2009JTECHA1231.1, 2009.

Peyridieu, S., Chd́in, A., Tanré, D., Capelle, V., Pierangelo, C., Lamquin, N., and Armante, R.: Saharan dust infrared optical depth and altitude retrieved from AIRS: a focus over North Atlantic - comparison to MODIS and CALIPSO, Atmos. Chem. Phys., 10, 1953-1967, doi:10.5194/acp-10-1953-2010, 2010.

Peyridieu, S., Chédin, A., Capelle, V., Tsamalis, C., Pierangelo, C., Armante, R., Crevoisier, C., Crépeau, L., Siméon, M., Ducos, F., 
and Scott, N. A.: Characterisation of dust aerosols in the infrared from IASI and comparison with PARASOL, MODIS, MISR, CALIOP, and AERONET observations, Atmos. Chem. Phys., 13, 6065-6082, doi:10.5194/acp-13-6065-2013, 2013.

Pierangelo, C., Chédin, A., Heilliette, S., Jacquinet-Husson, N., and Armante, R.: Dust altitude and infrared optical depth from AIRS, Atmos. Chem. Phys., 4, 1813-1822, doi:10.5194/acp-41813-2004, 2004.

Prenni, A. J., Petters, M. D., Kreidenweis, S. M., Heald, C. L., Martin, S. T., Artaxo, P., Garland, R. M., Wollny, A. G., and Pöschl, U.: Relative roles of biogenic emissions and Saharan dust as ice nuclei in the Amazon basin, Nat. Geosci., 2, 402-405, doi:10.1038/NGEO517, 2009.

Prospero, J. M. and Lamb, P. J.: African droughts and dust transport to the Caribbean: climate change implications, Science, 302, 1024-1027, doi:10.1126/science.1089915, 2003.

Prospero, J. M., Glaccum, R. A., and Nees, R. T.: Atmospheric transport of soil dust from Africa to South America, Nature, 289, 570-572, doi:10.1038/289570a0, 1981.

Prospero, J. M., Landing, W. M., and Schulz, M.: African dust deposition to Florida: temporal and spatial variability and comparisons to models, J. Geophys. Res., 115, D13304, doi:10.1029/2009JD012773, 2010.

Prospero, J. M., Bullard, J. E., and Hodgkins, R.: High-latitude dust over the North Atlantic: inputs from Icelandic proglacial dust storms, Science, 335, 1078-1082, doi:10.1126/science.1217447, 2012.

Quijano, A. L., Sokolik, I. N., and Toon, O. B.: Influence of the aerosol vertical distribution on the retrievals of aerosol optical depth from satellite radiance measurements, Geophys. Res. Lett., 27, 3457-3460, doi:10.1029/1999GL011235, 2000.

Redemann, J., Vaughan, M. A., Zhang, Q., Shinozuka, Y., Russell, P. B., Livingston, J. M., Kacenelenbogen, M., and Remer, L. A.: The comparison of MODIS-Aqua (C5) and CALIOP (V2 \& V3) aerosol optical depth, Atmos. Chem. Phys., 12, 3025-3043, doi:10.5194/acp-12-3025-2012, 2012.

Reid, J. S., Westphal, D. L., Livingston, J. M., Savoie, D. L., Maring, H. B., Jonsson, H. H., Eleuterio, D. P., Kinney, J. E., and Reid, E. A.: Dust vertical distribution in the Caribbean during the Puerto Rico Dust experiment, Geophys. Res. Lett., 29, 1151, doi:10.1029/2001GL014092, 2002.

Reid, J. S., Kinney, J. E., Westphal, D. L., Holben, B. N., Welton, E. J., Tsay, S.-C., Eleuterio, D. P., Campbell, J. R., Christopher, S. A., Colarco, P. R., Jonsson, H. H., Livingston, J. M., Maring, H. B., Meier, M. L., Pilewskie, P., Prospero, J. M., Reid, E. A., Remer, L. A., Russell, P. B., Savoie, D. L., Smirnov, A., and Tanre, D.: Analysis of measurements of Saharan dust by airborne and groundbased remote sensing methods during the Puerto Rico Dust Experiment (PRIDE), J. Geophys. Res., 108, 8586, doi:10.1029/2002JD002493, 2003.

Remer, L. A., Kaufman, Y. J., Tanre, D., Matoo, S., Chu, D. A., Martins, J. V., Li, R.-R., Ichoku, C., Levy, R. C., Kleidman, R. G., Eck, T. F., Vermote, E., and Holben, B. N.: The MODIS aerosol algorithm, products, and validation, J. Atmos. Sci., 62, 947-973, doi:10.1175/JAS3385.1, 2005.

Remer, L. A., Kleidman, R. G., Levy, R. C., Kaufman, Y. J., Tanre, D., Mattoo, S., Martins, J. V., Ichoku, C., Koren, I., Yu, H., and Holben, B. N.: Global aerosol climatology from the MODIS satellite sensors, J. Geophys. Res., 113, D14S07, doi:10.1029/2007JD009661, 2008.

Ridley, D. A., Heald, C. L., and Ford, B.: North African dust export and deposition: a satellite and model perspective, J. Geophys. Res., 117, D02202, doi:10.1029/2011JD016794, 2012.

Rodríguez, S., Alastuey, A., Alonso-Pérez, S., Querol, X., Cuevas, E., Abreu-Afonso, J., Viana, M., Pérez, N., Pandolfi, M., and de la Rosa, J.: Transport of desert dust mixed with North African industrial pollutants in the subtropical Saharan Air Layer, Atmos. Chem. Phys., 11, 6663-6685, doi:10.5194/acp-11-66632011, 2011.

Sassen, K., DeMott, P. J., Prospero, J. M., and Poellot, M. R.: Saharan dust storms and indirect aerosol effects on clouds: CRYSTAL-FACE results, Geophys. Res. Lett., 30, 1633, doi:10.1029/2003GL017371, 2003.

Schepanski, K., Tegen, I., and Macke, A.: Saharan dust transport and deposition towards the tropical northern Atlantic, Atmos. Chem. Phys., 9, 1173-1189, doi:10.5194/acp-9-1173-2009, 2009.

Schuster, G. L., Vaughan, M., MacDonnell, D., Su, W., Winker, D., Dubovik, O., Lapyonok, T., and Trepte, C.: Comparison of CALIPSO aerosol optical depth retrievals to AERONET measurements, and a climatology for the lidar ratio of dust, Atmos. Chem. Phys., 12, 7431-7452, doi:10.5194/acp-12-7431-2012, 2012.

Shell, K. M. and Somerville, R. C. J.: Sensitivity of climate forcing and response to dust optical properties in an idealized model, J. Geophys. Res., 112, D03206, doi:10.1029/2006JD007198, 2007. Smirnov, A., Holben, B. N., Giles, D. M., Slutsker, I., O’Neill, N. T., Eck, T. F., Macke, A., Croot, P., Courcoux, Y., Sakerin, S. M., Smyth, T. J., Zielinski, T., Zibordi, G., Goes, J. I., Harvey, M. J., Quinn, P. K., Nelson, N. B., Radionov, V. F., Duarte, C. M., Losno, R., Sciare, J., Voss, K. J., Kinne, S., Nalli, N. R., Joseph, E., Krishna Moorthy, K., Covert, D. S., Gulev, S. K., Milinevsky, G., Larouche, P., Belanger, S., Horne, E., Chin, M., Remer, L. A., Kahn, R. A., Reid, J. S., Schulz, M., Heald, C. L., Zhang, J., Lapina, K., Kleidman, R. G., Griesfeller, J., Gaitley, B. J., Tan, Q., and Diehl, T. L.: Maritime aerosol network as a component of AERONET - first results and comparison with global aerosol models and satellite retrievals, Atmos. Meas. Tech., 4, 583-597, doi:10.5194/amt-4-583-2011, 2011.

Sun, D., Lau, K. M., and Kafatos, M.: Contrasting the 2007 and 2005 hurricane seasons: evidence of possible impacts of Saharan dry air and dust on tropical cyclone activity in the Atlantic basin, Geophys. Res. Lett., 35, L15405, doi:10.1029/2008GL034529, 2008.

Tesche, M., Gross, S., Ansmann, A., Muller, D., Althausen, D., Freudenthaler, V., and Esselborn, M.: Profiling of Saharan dust and biomass-burning smoke with multiwavelength polarization Raman lidar at Cape Verde, Tellus, 63, 649-676, doi:10.1111/j.1600-0889.2011.00548.x, 2011.

Thorsen, T. J., Fu, Q., and Comstock, J.: Comparison of the CALIPSO satellite and ground-based observations of cirrus clouds at the ARM TWP sites, J. Geophys. Res., 116, D21203, doi:10.1029/2011JD015970, 2011.

Tompkins, A. M., Cardinali, C., Morcrette, J.-J., and Rodwell, M.: Influence of aerosol climatology on forecasts of the African Easterly Jet, Geophys. Res. Lett., 32, L10801, doi:10.1029/2004GL022189, 2005. 
Torres, O., Tanskanen, A., Veihelmann, B., Ahn, C., Braak, R., Bhartia, P. K., Veefkind, P., and Levelt, P.: Aerosols and surface UV products from Ozone Monitoring Instrument observations: an overview, J. Geophys. Res., 112, D24S47, doi:10.1029/2007JD008809, 2007.

Twohy, C. H., Kreidenweis, S. M., Eidhammer, T., Browell, E. V., Heymsfield, A. J., Bansemer, A. R., Anderson, B. E., Chen, G., Ismail, S., DeMott, P. J., and Van Den Heever, S. C.: Saharan dust particles nucleate droplets in eastern Atlantic clouds, Geophys. Res. Lett., 36, L01807, doi:10.1029/2008GL035846, 2009.

Uno, I., Eguchi, K., Yumimoto, K., Takemura, T., Shimizu, A., Uematsu, M., Liu, Z., Wang, Z., Hara, Y., and Sugimoto, N.: Asian dust transported one full circuit around the globe, Nat. Geosci., 2, 557-560, 2009.

van der Werf, G. R., Randerson, J. T., Collatz, G. J., and Giglio, L.: Carbon emissions from fires in tropical and subtropical ecosystems, Glob. Change Biol., 9, 547-562, doi:10.1046/j.13652486.2003.00604.x, 2003.

Vaughan, M. A., Powell, K. A., Kuehn, R. E., Young, S. A., Winker, D. M., Hostetler, C. A., Hunt, W. H., Liu, Z., McGill, M. J., and Getzewich, B. J.: Fully automated detection of cloud and aerosol layers in the CALIPSO lidar measurements, J. Atmos. Ocean. Tech., 26, 2034-2050, doi:10.1175/2009JTECHA1228.1, 2009.

Voss, K. J., Welton, E. J., Quinn, P. K., Johnson, J., Thompson, A. M., and Gordon, H. R.: Lidar measurements during Aerosols99, J. Geophys. Res., 106, 20821-20831, doi:10.1029/2001JD900217, 2001.

Waliser, D. E. and Gautier, C.: A satellite-derived climatology of the ITCZ, J. Climate, 6, 2162-2174, doi:10.1175/15200442(1993)006<2162:ASDCOT>2.0.CO;2, 1993.

Wandinger, U., Tesche, M., Seifert, P., Ansmann, A., Muller, D., and Althausen, D.: Size matters: Influence of multiple scattering on CALIPSO light-extinction profiling in desert dust, Geophys. Res. Lett., 37, L10801, doi:10.1029/2010GL042815, 2010.

Wang, K.-Y.: Profiles of the atmospheric temperature response to the Saharan dust outbreaks derived from FORMOSAT3/COSMIC and OMI AI, Atmos. Res., 96, 110-121, doi:10.1016/j.atmosres.2009.11.017, 2009.

Weinzierl, B., Sauer, D., Esselborn, M., Petzold, A., Veira, A., Rose, M., Mund, S., Wirth, M., Ansmann, A., Tesche, M., Gross, S., and Freudenthaler, V.: Microphysical and optical properties of dust and tropical biomass burning aerosol layers in the Cape Verde region-an overview of the airborne in situ and lidar measurements during SAMUM-2, Tellus, 63, 589-618, doi:10.1111/j.1600-0889.2011.00566.x, 2011.

Wilcox, E. M., Lau, K. M., and Kim, K.-M.: A northward shift of the North Atlantic Ocean Intertropical Convergence Zone in response to summertime Saharan dust outbreaks, Geophys. Res. Lett., 37, L04804, doi:10.1029/2009GL041774, 2010.

Winker, D. M., Hunt, W. H., and McGill, M. J.: Initial performance assessment of CALIOP, Geophys. Res. Lett., 34, L19803, doi:10.1029/2007GL030135, 2007.

Winker, D. M., Vaughan, M. A., Omar, A., Hu, Y., Powell, K. A., Liu, Z., Hunt, W. H., and Young, S. A.: Overview of the CALIPSO mission and CALIOP data processing algorithms, J. Atmos. Ocean. Tech., 26, 2310-2323, doi:10.1175/2009JTECHA1281.1, 2009.
Winker, D. M., Pelon, J., Coakley Jr., J. A., Ackerman, S. A., Charlson, R. J., Colarco, P. R., Flamant, P., Fu, Q., Hoff, R. M., Kittaka, C., Kubar, T. L., Le Treut, H., McCormick, M. P., Megie, G., Poole, L., Powell, K., Trepte, C., Vaughan, M. A., and Wielicki, B. A.: The CALIPSO mission: a global 3D view of aerosols and clouds, B. Am. Meteorol. Soc., 91, 1211-1229, doi:10.1175/2010BAMS3009.1, 2010.

Winker, D. M., Tackett, J. L., Getzewich, B. J., Liu, Z., Vaughan, M. A., and Rogers, R. R.: The global 3-D distribution of tropospheric aerosols as characterized by CALIOP, Atmos. Chem. Phys., 13, 3345-3361, doi:10.5194/acp-13-3345-2013, 2013.

Wong, S. and Dessler, A. E.: Suppression of deep convection over the tropical North Atlantic by the Saharan Air Layer, Geophys. Res. Lett., 32, L09808, doi:10.1029/2004GL022295, 2005.

Wong, S., Dessler, A. E., Mahowald, N. M., Yang, P., and Feng, Q.: Maintenance of lower tropospheric temperature inversion in the Saharan Air Layer by dust and dry anomaly, J. Climate, 22, 5149-5162, doi:10.1175/2009JCLI2847.1, 2009.

Wu, D. L., Chae, J. H., Lambert, A., and Zhang, F. F.: Characteristics of CALIOP attenuated backscatter noise: implication for cloud/aerosol detection, Atmos. Chem. Phys., 11, 2641-2654, doi:10.5194/acp-11-2641-2011, 2011.

Wu, L.: Impact of Saharan air layer on hurricane peak intensity, Geophys. Res. Lett., 34, L09802, doi:10.1029/2007GL029564, 2007.

Wu, M.-L. C., Reale, O., Schubert, S. D., Suarez, M. J., Koster, R. D., and Pegion, P. J.: African Easterly Jet: structure and maintenance, J. Climate, 22, 4459-4480, doi:10.1175/2009JCLI2584.1, 2009.

Yang, W., Marshak, A., Várnai, T., Kalashnikova, O. V., and Kostinski, A. B.: CALIPSO observations of transatlantic dust: vertical stratification and effect of clouds, Atmos. Chem. Phys., 12, 11339-11354, doi:10.5194/acp-12-11339-2012, 2012.

Yu, H., Chin, M., Winker, D. M., Omar, A. H., Liu, Z., Kittaka, C., and Diehl, T.: Global view of aerosol vertical distributions from CALIPSO lidar measurements and GOCART simulations: regional and seasonal variations, J. Geophys. Res., 115, D00H30, doi:10.1029/2009JD013364, 2010.

Zagar, N., Skok, G., and Tribbia, J.: Climatology of the ITCZ derived from ERA Interim reanalyses, J. Geophys. Res., 116, D15103, doi:10.1029/2011JD015695, 2011.

Zhang, C. and Pennington, J.: African dry air outbreaks, J. Geophys. Res., 109, D20108, doi:10.1029/2003JD003978, 2004.

Zhang, J. and Zhang, Q.: Aerosol impact and correction on temperature profile retrieval from MODIS, Geophys. Res. Lett., 35, L13818, doi:10.1029/2008GL034419, 2008.

Zhu, A., Ramanathan, V., Li, F., and Kim, D.: Dust plumes over the Pacific, Indian, and Atlantic oceans: climatology and radiative impact, J. Geophys. Res., 112, D16208, doi:10.1029/2007JD008427, 2007.

Zipser, E. J., Twohy, C. H., Tsay, S.-C., Lee Thornhill, K., Tanelli, S., Ross, R., Krishnamurti, T. N., Ji, Q., Jenkins, G., Ismail, S., Hsu, N. C., Hood, R., Heymsfield, G. M., Heymsfield, A., Halverson, J., Goodman, H. M., Ferrare, R., Dunion, J. P., Douglas, M., Cifelli, R., Chen, G., Browell, E. V., and Anderson, B.: The Saharan Air Layer and the fate of African Easterly Waves-NASA's AMMA field study of tropical cyclogenesis, B. Am. Meteorol. Soc., 90, 1137-1156, doi:10.1175/2009BAMS2728.1, 2009. 